\title{
Climate Change, Insurance, and the Buildings Sector: Technological Synergisms between Adaptation and Mitigation
}

\author{
Forthcoming in Building Research and Information \\ Special Issue: Preparing for Climate Change \\ Evan Mills, Ph.D. \\ Staff Scientist \\ Lawrence Berkeley National Laboratory \\ MS 90-4000 \\ Berkeley, CA \\ 94720 \\ USA \\ $\mathrm{T}:+1.510 .486-6784$ \\ F: +1.510.486-6996 \\ E: emills@1bl.gov
}

October 2002

LBNL-50967

\begin{abstract}
Examining the intersection of risk analysis and sustainable energy strategies reveals numerous examples of energy efficient and renewable energy technologies that offer insurance loss-prevention benefits. The growing threat of climate change provides an added motivation for the risk community to better understand this area of opportunity. While analyses of climate change mitigation typically focus on the emissions-reduction characteristics of sustainable energy technologies, less often recognized are a host of synergistic ways in which these technologies also offer adaptation benefits, e.g. making buildings more resilient to natural disasters. While there is already some relevant activity, there remain various barriers to significantly expanding these efforts. Achieving successful integration of sustainable energy considerations with risk-management objectives requires a more proactive orientation, and coordination among diverse actors and industry groups.

Disclaimer: This document was prepared as an account of work sponsored by the United States Government. While this document is believed to contain correct information, neither the United States Government nor any agency thereof, nor The Regents of the University of California, nor any of their employees, makes any warranty, express or implied, or assumes any legal responsibility for the accuracy, completeness, or usefulness of any information, apparatus, product, or process disclosed, or represents that its use would not infringe privately owner rights. Reference herein to any specific commercial product, process, or service by its trade name, trademark, manufacturer, or otherwise, does not necessarily constitute or imply its endorsement, recommendation, or favoring by the United States Government or any agency thereof, or The Regents of the University of California. The views and opinions of authors expressed herein do not necessarily state or reflect those of the United States Government of any agency thereof, or The Regents of the University of California.
\end{abstract}




\title{
Introduction
}

\author{
"Everybody talks about the weather, but nobody does anything about it." \\ -- Charles Dudley Warner (Hartford Courant, 1897, quoted in Thorness \\ 1998)
}

This article describes the significance of global climate change for the insurance industry and the particular dual role that energy efficient and renewable energy technologies can play in mitigating greenhouse-gas emissions while increasing adaptive capacity by making buildings more disaster-resilient.

Natural disasters and relatively small events resulting from weather extremes have wellknown consequences for the insurance and risk-management industries. These losses are on the rise (Figure 1). The dimensions of current global losses (number of events, fatalities, economic losses, and insured losses) are outlined in Figure 2. A larger share of losses are insured in Australia, Europe, and the North/Central America than in the rest of the world. The majority of "catastrophe" losses are due to weather-related events in all parts of the world, although the exact proportion varies considerably.

An array of associated vulnerabilities and potential impacts pervade the broader society. As such, there is considerable recognized value in establishing disaster-resistant transportation, communication, and energy supply systems. The buildings sector is perhaps the most vulnerable, with exposures ranging from damage to physical infrastructure to disruption of business operations to adverse health and safety consequences for building occupants (Camilleri et al. 2001; Lowe 2001a; Vellinga et al. 2001; Scott et al. 2001). A range of events are of concern, including windstorm, hurricane, tropical cyclone, hailstorm, flood, drought, lightning, wildfire, extreme temperature episodes, and sea-level rise and tidal surges.

Climate change, and the consequences of associated extreme weather events have provided a motivation for the insurance community to better understand and promote sustainable energy technologies. While analyses of climate change responses typically focus on the emissions-reduction ("mitigation") characteristics of renewable and demandside energy technologies, less often recognized are a host of ways in which these technologies also offer adaptation benefits, e.g. making buildings more resilient to natural disasters (Lowe 2001b).

\section{Impacts of Climate Change on the Insurance Industry}

Extreme weather-related events have impacted almost all types of insurance providers. The degree of vulnerability to climate change depends on the degree of climate change and by type of insurance in question (Table 1). Low levels of climate change are expected to have mixed positive and negative impacts, with a strong trend towards net negative impacts as the degree of climate change increases (Figure 3). 
Property insurers are generally believed to be more vulnerable to climate change than are life and health insurers (Vellinga et al., 2001), although concerns have been expressed for both sides of the industry (e.g. Ross 2000). Climate change impacts in the buildings sector are the primary concern for property insurers, given the extent of insured value represented, and the vulnerability as compared to other infrastructure.

The effects of increased losses can lead to pressure on insurance prices, sensitivity of insurers' stock value to major weather-related events, and increased insolvencies (Mills et al. 2001) (Figure 4a-b). Large and small insurers alike have been impacted by weather extremes and will be more so in the future if the frequency or intensity of these events increases (Vellinga et al. 2001). It follows that the continued insurability of such risks is a central question, as insurers may seek to withdraw coverages from selected areas.

Interestingly, the earliest documented statement of insurer concern about global climate change dates back nearly 30 years (Munich Re 1973). Insurers later participated in the intensively peer-reviewed work of the Intergovernmental Panel on Climate Change (IPCC) in 1995, leading the authorship of an entire chapter devoted to the question (Dlugolecki 1995). Two chapters in the subsequent IPCC Assessment published six years later also focused a diversity of potential climate change impacts on insurers (Table 1) (Vellinga et al. 2001; Cohen et al. 2001). ${ }^{1}$ Among their findings:

- Observed upward trends in insurance losses are consistent with what would be expected under climate change.

- There is high confidence that climate change and associated changes in weatherrelated events would increase actuarial uncertainty in risk assessment, and thus adversely affect the functioning of insurance markets, e.g. pricing and availability.

- Despite isolated benefits (e.g. fewer frost days), climate change scenarios will result in elevated potential for insurer bankruptcies, ${ }^{2}$ for large and small firms alike.

\footnotetext{
${ }^{1}$ In addition to a variety of climate scientists, insurance and banking, industry co-authors included representatives from CGU, Credit Suisse, The Insurance Bureau of Canada, Munich Re, and Tokyo Marine \& Fire Insurance, Co., Ltd., and an actuary from the United States.

2 The threat of insolvency (bankruptcy) is often assumed to apply exclusively to small firms. Following Hurricane Andrew, however, the United States' largest homeowner property insurer, State Farm Fire \& Casualty, was brought to the brink of insolvency, necessitating a rescue by its parent (State Farm Group). Allstate, the nation's second largest homeowner insurer, met the same fate (Mills et al. 2001). Of the nearly 700 U.S. insurers that became insolvent between 1969 and 1999, about $10 \%$ of the cases were primarily due to natural catastrophes, and for an unknown additional share catastrophes were a contributing but not primary factor (Matthews et al. 1999).
} 
- Insurability concerns in an environment of increasing natural disasters will put increasing pressure on the often-reluctant government sector to assume certain risks.

-Various climate-change prevention strategies offer interesting business opportunities for insurers, e.g. insurance of contracts to reduce emissions, and synergisms between adaptation and mitigation.

Irrespective of the causes of past losses, a key problem looking forward is that climate science is rarely designed to address questions of importance to insurers. The growing use of catastrophe ("CAT") models is a step in the right direction, although these models are hamstrung by virtue of being predicated largely on historical data rather than scenarios incorporating future climate change. CAT models help insurers conduct scenarios of property damage for different types of event and localities, but often fail to capture smaller-scale, but more frequent events of concern such as wildfire, lightning strikes, soil subsidence, and localized flooding.

Increasingly variable and unpredictable patterns of extreme weather events can imply greater statistical uncertainty (unpredictability) of potential losses. This can present a material impediment to setting actuarially sound rates and making insurance available to those who need it (Peara and Mills 1999). The prospect of rapid non-linear climate change is particularly threatening to the risk management industries. Examples include variability and transitions of hemispheric-scale ocean-thermal ("thermohaline") circulation patterns, glacial and polar ice-cap instability, biogeochemical cycles and sources/sinks of radiative gasses, radiative forcing and potential impacts on atmospheric dynamics, and a variety of potential interactions among the aforementioned phenomenon (IPCC 1998).

"Insurers rely upon their ability to predict the economic consequences of future events. ... In a period of changing climate, when the very basis of their decisions may be changing, then they need to have a better understanding of climate change... The fact that future events may not be a linear progression of the past, but in fact may have changed as a result of natural variability, or human activity or whatever, is an important thing to be taken into consideration."

- Franklin Nutter (Business Insurance 1998)

Munich Re's Geosciences Group (2000) has tabulated that over the 1985-2000 time period, the nations of the world have endured nearly one trillion dollars in economic losses (and 170,000 fatalities) due to 8,800 natural disasters. Three-quarters of the aforementioned losses were weather-related, and a fifth were insured.

Over the past 50 years, the number of weather-related natural disasters has been steadily rising, as have the total and insured losses (Figure 1). A multitude of factors have contributed to the scale and rate of change in losses, ranging from economic and demographic trends to changes in the nature of natural disasters themselves. 
One of the vexing analytical challenges facing insurers is the difficulty of quantitatively disentangling the causes of weather-related loss events. This is especially true for those potentially related to human-induced climatic change versus natural climate cycles, and those having to do with human activity that could accelerate or dampen the process (demographic trends, increasing property values, disaster mitigation efforts, etc.) (Hooke 2000). It is generally agreed that the current upward trend in losses is a product of both human and climatological factors, but an in-depth understanding is hampered by technical complexity and insufficient data (Vellinga et al. 2001). One effort by Munich Re ascribed about half of the past rise in losses to climate change and the remainder to socio-economic trends (Munich Re 1999).

After subtracting the effects of inflation, global weather-related insurance losses from large events escalated from a negligible level in the 1950s to an average of $\$ 9.2$ billion (\$1999) per year in the 1990s_- or 13.6-fold for the 1960-1999 period where detailed base-year data are available. ${ }^{3}$ Insured losses as a percent of gross domestic product also rose (Swiss Re 1997), and the ratio of losses to premium revenues declined by a factor of ten (Vellinga et al., 2001). A comparison of the decades since 1950 reveals that population grew by only 2.4 -fold during this period.

It is clear that the costs of weather events have risen rapidly, despite significant and increasing efforts at fortifying infrastructure and enhancing disaster preparedness. These efforts have dampened to an unknown degree the observed rise in loss costs, although the literature attempting to separate natural from human driving forces has not quantified this effect.

A disproportionate amount of attention is paid to the headline-grabbing multi-billion dollar loss events, given the equally large (albeit more distributed) collective costs of relatively minor events expected under climate change. For example, the average annual cost of tornadoes and associated hailstorms is larger than that of hurricanes or earthquakes (Swiss Re 2000a). If one includes mid-sized weather-related loss events - more than 600 of which are documented every year-the economic losses cited above double (Munich Re 2000). Large events represent only $1 \%$ of the total number of weather-related events annually.

One important yet often-overlooked class of small events are those involving damage to buildings and pipelines due to soil subsidence (contraction/expansion of soil as a function of moisture content), lightning, ordinary hail- and windstorms, and coastal erosion. Subsidence losses from two droughts in the 1990s resulted in losses of $\$ 2.5$ billion in France and even more in the U.K. (Figure 5) (Vellinga et al. 2001).

Realistic future scenarios involve multiple, coincident events e.g. consecutive (or overlapping) natural disasters, taking place during a time of weakness in the financial markets and/or non-weather related losses. This was witnessed before in U.S. the case of the Great Depression and the Dust Bowl. Indeed, the impact of the terrorist attacks of

\footnotetext{
${ }^{3}$ These losses exclude administrative "loss-adjustment" costs; thus the total cost is higher.
} 
September $11^{\text {th }}, 2001$ will be amplified by a simultaneous downturn in the financial markets, the collapse of Enron, a recession, a steep decline in the securities markets, and emerging risks (e.g. toxic mold). A major weather-related catastrophe striking a US urban center could have the same or greater economic consequences as " $9 / 11$ ".

\section{Insurance Industry Responses}

The words "Climate Change" stir anxieties and arouse controversies among some insurers, especially in the U.S. (Mills et al. 2001). While a number have given some attention to the issue, the vast majority of individual firms and most trade organizations have not publicly indicated an opinion. Some have taken definitive positions that there is a material threat, while others have adopted equally strong views to the contrary. Some have elected to pursue research while promoting disaster preparedness. Others have adopted a strictly "wait-and-see" stance.

A core set of insurance firms have played a variety of roles in responding to the specter of climate change, ranging from technical and economic responses to political responses. Historically, much of the activity has been focused on preparing for and responding to natural disasters. Some elements of the industry are arguing for a more proactive approach going forward.

\section{Technical \& Economic Responses}

Many insurers have responded to the pronounced upward trend in losses by invoking traditional financial risk-management techniques, such as non-renewal of existing policies, withdrawing from high-risk markets, increasing premiums or deductibles, and limiting the maximum payouts allowed for a given claim. Insurers also purchase reinsurance, and endeavor to shift risks to self-insureds and the capital markets to protect themselves against catastrophic losses.

An additional important trend is the gradual shift towards increasing reliance on public sector insurance. This typically occurs in cases where losses are highly concentrated and unpredictable, such as flood and crop insurance. Federal and local governments, however, have repeatedly shown reluctance to increase their existing insurance exposures and liabilities for providing disaster relief. This tension is a central dilemma facing society and policymakers in the face of rising catastrophe losses. Analogous concerns have arisen concerning terrorism insurance in the wake of the attacks of September 11, 2001.

"Even the [U.S.] government is starting to feel the financial pinch of disaster aid. ... The enormous size of recent catastrophes and the potential for more of the same have caused the government to reevaluate its role as a provider of disaster relief."

-- Insurance Services Office (1994) 
More technically-focused risk-management efforts include use of geographic information systems to better understand and pinpoint risks, land-use planning, flood control programs, mitigation along coastlines, cloud seeding to divert hail storms, tightened zoning, improved weather forecasting and storm warning systems, and public spending on disaster preparedness and recovery. Insurers have also developed disaster preparedness and recovery plans, and participated in the formulation of building codes to make buildings more disaster-resistant. Formulation of early building codes in the U.S. were driven by insurers aiming to reduce their fire-related exposures. The U.S.-based Insurance Institute for Property Loss Reduction (now the Institute for Business and Home Safety) identified considerable lack of knowledge among code-inspection officials and implemented training programs in response.

Some insurers have taken a more long-term approach, focusing on the roots of climate change rather than simply preparing for it. This includes participating in climate research either by employing climatologists or hiring outside experts. In another example, Munich Re systematically collects and analyzes natural catastrophe data and has participated in the work of the Intergovernmental Panel on Climate Change. Others, e.g. Arkwright Mutual (now part of FM Global) have contributed to the literature analyzing historic data in an effort to detect the climate-change "signal" (Zeng and Kelly 1997). Arkwright concluded that climate change is likely playing a role in the rise in flood losses, in combination with demographic trends.

A number of forward-looking insurers have explored possible involvements with energyefficient and renewable energy technologies. We reviewed steps taken by 52 insurers and reinsurers, 5 brokers, and 7 insurance organizations, and 13 non-insurance organizations in this arena (Mills 2002a). The approaches can be grouped into the categories of: information, education, and demonstration; financial incentives; specialized policies and products; direct investment to promote energy efficiency and renewables; value-added customer services and inspections; efficient codes, standards, and policies; research and development; and in-house energy management in insurer-owned properties (Table 3).

In some cases, insurers are developing green investment funds. Swiss Re has a "sustainability-based investment portfolio" approaching 100 million Swiss Francs (approximately $\$ 60$ million) in the form of venture capital and other investments (Swiss Re 2000b). As exemplified by the UK's Gerling Group, Swiss Re, Munich Re, CGU, Storebrand, and others, European insurers are more likely to adopt this perspective. Gerling has set up a \$100-million Sustainable Investment Fund in which several other insurers have invested to date.

"Sustainable strategies and value creation are not contradictory: Sustainable strategies lead to an increase of reputation, innovative capacity and better awareness of stakeholders' and customers' perceptions and needs. They also contribute to gain in efficiency and reduce risks."

-- Dirk Kohler, Gerling Sustainable Development Project (1999) 


\section{Political Responses}

European and Asian insurers have been particularly outspoken on the climate change issue:

"The situation we are in resembles that of a driver who approaches a wall of fog and, having only a vague impression of the stretch in front of him, looks into the rear mirror in an attempt to see in the clear view of the road behind some indication of what lies ahead... There are some drivers on this earth that, instead of stepping on the brake, are putting their foot down firmly on the accelerator... A further option entails active climate and environmental protection. This can lead to real win-win situations in the foreseeable future... Mankind is in the process of performing a gigantic experiment on the earth's climate. However possible it may still be to argue about the development of climate change and particularly about its effects, there are definite indications that the risk situation will deteriorate in the future. Every effort must be made to mitigate climate change and to restrict the impact as much as possible." -- Munich Re (1999)

A few U.S. insurers have been equally outspoken:

"Climate change is real. Proving that earth's climate is changed by human actions, namely global warming, is like statistically "proving" the pavement exists after you have jumped out a 30 story building. After each floor your analysis would say "so far - so good" and then, at the pavement, all uncertainty is removed."

- Richard Jones, Hartford Steam Boiler Insurance \& Inspection Company (2000)

Some have ventured into the realm of public policy-even in the United States-making statements and recommendations that are clearly outside of the traditional realm in which insurers operate.

"To avoid the costs of climate disruption, a shift in priorities, credits, subsidies and incentives will be needed to help develop technologies that steer us into a renewable and energy-efficient future. The biggest surprise may be the better distributed economic opportunities produced by this transition."

-- Harvard Center for Health and the Global Environment \& Reinsurance Association of America (Epstein and Nutter 1997)

A number of insurers have chosen to "lead by example", e.g. by addressing the environmental performance of their own facilities and operations. These efforts have begun to be documented by corporate "Environmental Annual Reports". Swiss Re's is particularly notable in the extensive integration with operating units within the company, including: services and products, investments, facilities and operations, information technology, and human resources (Swiss Re 2000b). Swiss Re's reports include 
quantification of environmental indicators such as carbon dioxide emissions associated with corporate operations, and goals such as an emissions reduction of $10 \%$ per employee for business travel. Norway's Storebrand also has an impressive report, which also evidences widespread penetration of environmentally-oriented management practices throughout the company (Storebrand 1999).

The most prominent political activity centers around approximately 90 insurers from 27 countries currently collaborating under the United Nations Insurance Industry Initiative for the Environment (UNEP 1999). The signatories have presented a series of position papers at international negotiations under the United Nations Framework Convention on Climate Change, and focus on concrete actions that the insurance industry can take to help society cope with climate risks.

\section{Differences between U.S. and non-U.S. Insurers}

With important exceptions, U.S. insurers have devoted relatively less attention to the issue than their counterparts in Asia and Europe and few have joined the aforementioned UNEP initiative. The primary differentiating factor is the relative interest of non-US insurers in the precautionary principle, and belief that both natural and human-induced climate changes are at play.

"It would be prudent for the property/casualty industry to act as if that theory [global warming] is correct. Failure to act would leave the industry and its policyholders vulnerable to truly disastrous consequences"

-- H.R. Kaufmann, Swiss Re's General Manager in 1990 (Quirke 1994)

"Risk management views the public discussion on climate change as a rabbit sitting paralyzed in front of a snake -- unaware that behind it a fox is poised to strike. There is not one problem but two: natural climate variability and the influence of human activity on the climate system."

-- Swiss Reinsurance Company (1998)

The following points illustrate some of the sources of these differences (from Mills et al., 2001).

- Overseas insurers have been studying the question of climate change much longer than have their U.S. counterparts (Munich Re 1973). There is a greater tradition of science among European insurers and more staff climatologists providing analyses and corporate strategic counsel (although this work is concentrated in a few major companies). Munich Re has the largest climatology research activity within the insurance industry, with a staff of thirty-five people.

- The debate about the scientific validity of climate change is particularly polarized in the United States, and most of the highly visible "climate skeptics" are based there. 
- Some of the largest U.S. carriers do not conduct business overseas, whereas European and Asian companies typically have multi-country markets and thus experience a broader range of risks of natural disaster exposures and risk-management challenges.

- Non-US reinsurers are heavily impacted by U.S. natural-disaster insurance losses. This was illustrated by a simulation study of two \$7-billion hurricanes in the U.S. The surprising result showed that $5 \%$ of participating European insurers became insolvent (bankrupt), versus 1.5\% of participating U.S. insurers (AIRAC 1986).

- "Green" politics and ideals are far more established and influential in some overseas political systems. Accordingly, "Green" marketing and product branding is ascribed a lower value in the U.S. than in many other countries, especially Europe.

- There is less government insurance for flood and crop losses in many other countries, and hence greater vulnerability among private insurers.

- There is a "cultural" and corporate tendency among U.S. insurers to focus somewhat exclusively on the effects of natural disasters, whereas in some other countries there is an additional interest in focusing on and addressing causes. This is at times reflected in the very definition of terms, e.g. the Canadians include the reduction of greenhouse gases in their definition of "mitigation" whereas U.S. insurers would tend to limit the use of this word to disaster preparedness.

- There is less of an adversarial relationship with insurers and their regulators in many countries, as compared to the situation in the United States. Engagement in the climate change issue would likely invoke increased need for regulator-insurer interaction.

- Tax laws pertaining to reserving for disaster reserves vary among countries. Some believe that the non-taxability of reserves in certain countries outside the U.S. provides an extra incentive for insurers there to accept the global warming thesis. Conversely, some postulate that if U.S. insurers voice agreement with the global warming theory that they will then be forced by their regulators to establish such (highly taxed) reserves.

- Unique to the U.S. are considerable negative lingering associations between Superfund and environmental concerns. Any environmental proposition automatically invokes the specter of Superfund. Asbestos litigation has also contributed to the industry's aversion to anything labeled "environmental".

- The UNEP Insurance Industry Initiative did not obtain participation of U.S. insurers during its formation and has not made a concerted effort to reach out to U.S. firms since that time. Nor have they attempted to recast their message in terms that clarify its relevance and value in the U.S. insurance market and regulatory context. 
One frequent manifestation of the various differences between U.S. and non-U.S. insurer perspectives is the virtual absence of U.S. insurer perception that climate change mitigation could offer business opportunities and other financial co-benefits for insurers (Zwirner 2000). Overseas insurers, primarily in Europe have, in contrast, been rather active in identifying opportunities and turning them into business realities, e.g. in thoughtfully identifying emerging markets based on the "Flexible Mechanisms" proposed in the Kyoto Protocol (Hugenschmidt and Janssen; Swiss Re 2000b; UNEP 1999).

In some cases, overseas insurers are developing green investment funds. Swiss Re has a "sustainability-based investment portfolio" approaching 100 million Swiss Francs (approximately $\$ 60$ million) in the form of venture capital and other investments (Swiss Re 2000b). As exemplified by the UK's Gerling Group, Swiss Re, Munich Re, CGU, Storebrand, and others, European insurers are more likely to adopt this perspective. Gerling has set up a \$100-million Sustainable Investment Fund, in which several other insurers have invested to date.

\section{Novel Approaches: Integrating Adaptation with Mitigation}

The insurance industry traditionally has little concern about energy issues. However, we have identified numerous examples of energy-efficient and renewable energy technologies that offer insurance loss-prevention benefits, and have mapped these opportunities onto the appropriate segments of the very diverse insurance sector (life, health, property, liability, business interruption, etc.) (Mills and Knoepfel 1996). Our recent inventory revealed 78 specific examples that offered risk-management benefits (Vine et al. 1998). We identified eight specific relevant "physical perils", and 15 corresponding types of insurance coverage (Table 2). A subset offer benefits in the event of natural disasters.

The examples described below are highly cost effective in most applications, i.e. the net present value of the energy they save is greater than their incremental first cost (Moomaw et al., 2001). Thus, no incremental cost is associated with the disaster-adaptation benefits. Policies and programs for achieving implementation, and the potential role of insurers therein are discussed at length by Mills (1996; 2002a). 


\section{Ice-dam-resistant Construction}

Repeated melting and re-freezing of snow can form icicles and ice dams on roof eaves. Melting water tends to pond on the rooftop, behind the ice dam, often causeing insured damage to the roof and the building interior. Water runoff or falling ice from rooftops can also present safety hazards. Ice dam formation is accelerated by preventable ex-filtration of warm air, insufficient insulation levels and thermal short circuits, or leaky heating ducts or light fixtures in otherwise cool attics (Figure 6). Electric heating elements often installed along rooflines are intended to provide a drainage channel for the water, but they was estimated to have resulted in 10,000 to 15,000 such water damage claims, with an average cost of $\$ 2,000$ per home (Levik 1996).

\section{Renewables and Energy Efficiency for Power Disruptions}

Loss of power can cause significant insured business interruptions and damage to property (Eto et al. 2001; Mills 2001a). There are a variety of ways to maintain business continuity through the use of reliable energy supplies and disaster resilient energy service systems. All forms of energy efficiency are of value when buildings must rely upon local backup power systems during times of outages. Refrigeration offers a clear example of the benefits: High-efficiency food and pharmaceutical storage systems will maintain critical temperatures longer in the absence of power, and will be easier (less power demand) to operate on backup generators. Perished food in residential freezers was one of the larger costs faced by homeowner insurers in the great North American Ice Storm of 1998 (Kovacs 2000). Renewable energy can also play a variety of roles, ranging from providing power for emergency shelters and schools, water purification systems, and backup for critical systems such as fuel pumps and safety lighting, although these systems are vulnerable to natural disasters.

\section{Energy-efficient Windows and Wall Construction for Wildfire \& Windstorm}

During a fire, heat-stressed windows can shatter as a result of differential expansion near the frames, and the increased supply of air flowing through a broken window accelerates the spread of fire and toxic fumes. Efficient windows reduce the likelihood that fire will cause breakage (Kluver 1994). Efficient multiple-pane windows or windows with retrofit films can reduce energy losses by half or more and are also more resistant to breakage by windstorms (by holding shards of broken glass together and maintaining a barrier against blowing wind and rain) and by thieves. They also block damaging UV radiation, and enhance occupant comfort (Mills and Rosenfeld 1996). Tests conducted by Lund University's Institute of Fire Technology for the Swedish company Pilkington Glass AB identified superior performance of windows with low-emissivity (energy-efficient) coatings (Anderberg 1985). For example, double-glazed units with one low-e coating took three- to four-times longer to break than did ordinary double-glazed units. In addition, these low-e double units performed as well or better than double units with one 
laminated glass layer. Efficient windows of course do not, of course, prevent the ignition of fires.

Improved building envelopes, e.g. with Insulated Concrete Form (ICF) techniques, are more energy-efficient and resistant to flying debris than standard timber-frame construction (Farnsworth 2000). Reduced infiltration may also provide benefits in the event of fires.

\section{Insulated Building Envelopes for Frozen Water Pipes}

In new construction, a clearly defined, continuous, and highly insulated thermal envelope, with all services placed inside, eliminates the risk of pipe freezing and the need for ad hoc insulation arrangements. The latter are difficult, time consuming, likely to be incomplete in the first place, and are vulnerable to removal during subsequent repair and maintenance. As a case in point, frozen water pipes have been identified as an important cause of losses in Europe and North America (Klaus et al. 1992). Cold winters correlate to significant reductions in the profitability of pipe insurance providers. The U.S. insurance industry paid $\$ 4.2$ billion in claims during a 10 -year period for freezing pipes (IBHS and SBA 1999). Insulating pipes (or cold spaces where pipes run) is a simple retrofit that saves energy and reduces the likelihood of freeze damage.

\section{Heat island Mitigation for Urban Heat Catastrophes and Smog Events}

Large cities are typically several degrees warmer than their surroundings because of the "urban heat island effect", even in the absence of climate change. Global climate change is expected to increase the frequency and severity of extreme-heat episodes (Watson et al., 2001). This increase in temperatures results in more urban smog (and associated health costs) and increased air conditioning energy use. Research has demonstrated that lightening the color of roads and building rooftops, and planting urban trees can dramatically reduce average urban temperatures (Mestel 1995). Detailed field studies have shown as much as $40-60 \%$ air conditioning savings in a series of buildings where these strategies were used (Rosenfeld et al. 1995). Lightened (or aluminized) exterior surfaces can also make a building less vulnerable to fire, especially if the materials are "tuned" to reject near-infrared radiation. An analysis of optimized paints found a potential 3.5-fold improvement in the "fire reflectance" of paints compared to typical white paint (Berdahl 1995a; 1995b; 1995). The use of trees to lower temperatures around buildings has also been found to have the side benefit of reducing the rate of water flow onto streets during downpours, and thus local flooding. Reducing urban air-shed temperatures also slows the formation of smog (Rosenfeld et al. 1995), which in turn reduces health insurance claims. Figures $7 \mathrm{a}-\mathrm{b}$ show how a package of measures including attic insulation, white paint on the roof, and ventilation would bring the indoor air temperature to safe levels in the kinds of apartments in which hundreds of heat deaths occurred in Chicago in 1995. Ultra-cold weather events of course also pose a risk to 
occupants of poorly insulated buildings, and can also be mitigated by energy-efficiency measures.

\section{LED Exit Signs for Building Evacuation}

Light-emitting-diode (LED) exit signs offer energy savings in excess of 90\% compared to traditional incandescent-based technologies (Mills 1993; Sardinsky and Hawthorne 1994). Their 10- 20-year service life means improved reliability and availability (and thus safety during emergencies) and less maintenance. The intense red LED light is highly visible through smoke. Given their low power demand, LED exit signs will operate longer during a power outage than traditional exit signs run by the same size battery.

\section{Integrating an Insurance Perspective with Broader Buildings Sector Issues}

Creating energy-efficient, disaster-resilient buildings is not only a technical challenge; it is an institutional one. An array of crises in the construction industry-ranging from construction defects liability to mold - reflect the need for better quality assurance, greater sophistication in the application of advanced technologies, and greater adherence to codes and standards. In the United States today, homebuilders are facing enormous lawsuits, estimated to cost (directly and indirectly) $\$ 200$ billion a year and to already be affecting the costs of homes (Golden 2002). Insurers are first in line to absorb some of these costs.

Achieving successful integration of sustainable energy considerations with riskmanagement objectives requires a more proactive orientation, and coordination among diverse actors. For example, government entities with jurisdiction over energy and emergency management rarely coordinate concerning energy demand-side issues. This creates barriers of various sorts, such as the absence of funding, information, and tolerance for rebuilding buildings in an energy-inefficient and disaster-prone manner.

A central consideration is to remodel or reconstruct buildings properly following disaster losses. Sustainable redevelopment is defined by the U.S. Department of Energy as "the deliberate effort by disaster-prone communities to improve their economic health, environmental resilience, and quality of life as they plan for and recover from natural disasters" (USDOE 1999).

Ensuring adequate knowledge and skills among building code enforcement individuals is a key need. The extensive property damage and loss of life due to inadequate codes or code enforcement has been evidenced many times following severe earthquakes in developing countries. Yet, these problems also haunt industrialized countries. For example, a survey by the U.S. Insurance Institute for Property Loss Prevention revealed that over $75 \%$ of U.S. code enforcement officials were inadequately equipped for this job. In the U.K., analysis of claims and weather data has shown that a large proportion of wind-related damage takes place at wind speeds lower than those to which buildings are 
nominally designed and are caused by failures to apply existing codes of practice (Buller 1993; Lowe 2001a).

While existing activities show that there is a remarkable level of sustainable-energy activity among insurers, there remain various barriers to significantly expanding the level of insurer participation. These barriers are summarized in Table 4 and discussed in length in Mills (2002a).

One significant barrier is that sustainable energy technologies can at times work at cross purposes to the goals of risk management (Mills and Knoepfel 1997; Vine, et al. 1998). Although the use of sustainable energy technologies and strategies generally reduces insurance risks - or is risk-neutral — if applied incorrectly energy management can compromise indoor air quality, cause water damage, pose fire hazards, etc. Various entities within the insurance community have made reference to such problems. The American Insurance Association, while supportive of certain efficiency options, has also stated that certain measures could present adverse risk characteristics (Unnewehr 1999). Even very pro-sustainability European insurers Gerling and Rheinland Versicherungen have been careful to flag potential downsides (Kohler 1999; Zwirner 2000). Perhaps the most widespread instance is the negative association between indoor air quality problems and energy efficiency in buildings (Frazer 1998; Diamond 1999). As a case-in-point, over \$100 million has been paid out for water damages caused by externally applied foam insulation retrofits (Deering 2001), and mold has become a crisis that insurers say may be as great as the one posed by asbestos. The replacement of electric cooking appliances with more energy-efficient gas devices can contribute to indoor air pollution (Jarvis et al. 1996). Some concerns are based on myths or misunderstandings of building science, as evidenced by the incorrect assertion that insulation exacerbates losses from frozen water pipes and ice dams (IBHS 2001). The legitimate problems are generally resolvable, but energy R\&D organizations (public as well as private) are driven largely if not exclusively by relatively narrow energy-related objectives and do not necessarily consider risk management issues. It is also prudent for sustainable energy enthusiasts to be thoughtful about the impacts of their proposals on the insurance sector's business environment.

The potential impacts of climate change on the buildings sector warrants the keen consideration of insurance regulators, given their dual responsibility as guardians of policyholders' interests and to assure the solvency of insurers so that they can meet their financial obligations when disaster strikes (Mills 2002b). In doing so, regulators must look at alternatives that will lessen the financial impact on insurers at the time of loss. Regulators can play many important roles, such as ensuring the collection and analysis of necessary data, and deploying appropriate risk-management technologies and practices. Notably, insurance regulations can inadvertently impede the more efficient use of energy. For example, insurers generally need regulatory approval for providing incentives to insureds to pursue loss-prevention strategies or to invest in sustainable energy industries. Similarly, the exclusion of research and development expenses from rates in some countries may stifle innovation in this area. 
Limited R\&D throughout the construction industry also generally creates barriers to identification, development and implementation of any package of measures aimed at long-term performance rather than first cost. This is a structural problem that severely restricts the ability of insurers (and indeed anybody else) to identify and advocate effective, integrated strategies for risk minimization. The first-cost orientation of consumers reinforces this counter-productive situation.

\section{Conclusions \& Policy Implications}

The insurance and risk-management industries are highly vulnerable to the impacts of climate change, particularly in the buildings sector. While traditional responses (raising premiums, withdrawing coverages, shifting the burden to the State, etc.), they are the most likely and the least politically and socially acceptable. Reduced insurance availability can have a chilling effect on the construction industry and real estate markets. A more optimistic scenario involves truly proactive approaches to addressing the climate change problem directly. In some instances, however, the insurance and buildings industries are at odds with one another; the former seeking to minimize losses and the latter to minimize first costs and regulatory oversight.

While not a panacea, one promising avenue is represented by the tremendous potential for insurers and risk managers to become more involved in utilizing energy efficiency and renewable energy as part of a broader strategy to make buildings more disasterresilient. Early precedents illustrate the wide array of ways in which insurers have already participated, but barriers also remain.

The challenge for the energy community is to continue to identify and articulate the ways in which these strategies can moderate or prevent insurance losses, and to make the business case of how sustainable energy technologies can improve the competitive advantage of insurance firms. To be successful, sustainable energy proposals must address acute strategic issues faced by insurers. A good example is the rapid growth in mold, indoor air quality, and construction defects claims haunting many insurers (Ruquet 2002); many of the claims trace back to bad design and application of energy-related systems. The growing insurance risks associated with electricity reliability are another example, which can be addressed, in part, through efficiency and distributed renewable energy supply solutions.

Lastly, a more diverse set of industry actors (agents, brokers, underwriters, risk managers, trade associations, and executives) must be educated and involved in assessing and implementing the opportunities. Conversely, the energy and building science communities, as well as the building trades, require a deeper understanding of insurance and risk management. 


\section{Acknowledgments}

This work was supported by the Assistant Secretary for Energy Efficiency and Renewable Energy. Office of Building Technology, State and Community Programs. Office of Building Research and Standards, U.S. Department of Energy under Contract No. DE-AC03-76SF00098 and the U.S. Environmental Protection Agency, Climate Protection Division, Contract DW8993901101. Lynn Price and two anonymous reviewers provided useful comments.

\section{References}

AIRAC. 1986. Catastrophic Losses: How the Insurance System Would Handle Two \$7 Billion Hurricanes. All-Industry Research Advisory Council (now the Insurance Research Council): Malvern, PA, 73 pp.

Anderberg, Y. 1985. Brandfoersoek paa glaskonstruktioner (Fire Research on Glass Construction). Lund University, Institute of Fire Technology, Lund, Sweden.

Berdahl, P. 1995a. "Building Energy Efficiency and Fire Safety Aspects of Reflective Coatings." Energy and Buildings 22. Elsevier Science Inc. 187-191.

Berdahl, P. 1995b. "Pigments to Reflect the Infrared Radiation from Fire", Journal of Heat Transfer, American Society of Mechanical Engineers, 117:355-358.

Berdahl, P. 1995. "Building Energy Efficiency and Fire Safety Aspects of Reflective Coatings", Energy and Buildings, 22:187-191.

Buller, P.S.J. 1993. A thirty year survey of gale damage to buildings in the UK. in Proc. $1^{\text {st }}$ IAWE European and African Regional Conf. Guersney. Watford: BRE.

Business Insurance. 1998. "Pushing Change before Weather Does: Shifts in Global Climate Should Spur Insurers to Challenge Assumptions, Industry Leader Says", Business Insurance. Interview with Franklin Nutter, (January 5), p. 3.

Camilleri, M., R. Jacques, and N. Isaacs. 2001. "Impacts of Climate Change on Building Performance in New Zealand.” Building Research \& Information 29(6):440-450.

Cohen, S., D. Schimel, G. Chilinsky, K. Duncan, E. Gregorich, P. Groffman, P. Kovacs, V. Magana, D. McKnight, K. Miller, E. Mills, D. Etkin, R. Flemming, K. Hall, J. Patz, D. Scott, G. Wall, r. Harris, E. Wheaton. 2001. "North America." Chapter 15 in "Climate Change 2001: Impacts, Vulnerability, and Adaptation." Intergovernmental Panel on Climate Change, United Nations and World Meteorological Organization, Geneva.

Deering, A. 2001. "Beyond Sick Building Syndrome: Mold Litigation Enters the Main Stream." Risk Management (November) p. 13-20.

Dlugolecki, A, K.M Clark, F. Knecht, D. McCaulay, J.P. Palutikof, W. Yambi. 1996. "Financial Services." Chapter 17 in Intergovernmental Panel on Climate Change (IPCC). Working Group II, Climate Change 1995: Impacts, Adaptations and Mitigation of Climate Change: Scientific and Technical Analyses, Cambridge University Press, pp. 539-560.

Epstein, P. and F. Nutter. 1997. "Climate Change Imposes Heavy Financial Cost." The New York Times (October 13). 
Eto, J., J. Koomey, B. Lehman, N. Martin, E. Mills, C. Webber, and E. Worrell. 2001. "Scoping Study on Trends in the Economic Value of Electricity Reliability to the U.S. Economy." LBNL-47911 http://eetd.lbl.gov/ea/EMS/reports/47026.pdf

Farnsworth, C.B. 2000. "Building for Disaster Mitigation." Home Energy Jan/Feb. pp. 28-33.

Gastel, R. 2000. Insolvencies/guaranty funds. Insurance Information Institute, New York, NY.

Golden, D.M. 2002. "Class-action Suites Threatening Homebuilders.” Business Insurance, June 24, p. 10.

Hooke, W.H. 2000. "U.S. Participation in International Decade for Natural Disaster Reduction." Natural Hazards Review, Vol. 1, No. 1, pp. 2-9.

Huang, Y.J. 1996. "Building Science Aspects to Urban Heat Catastrophes.” Poster presentation at the 1996 ACEEE Summer Study on Energy Efficiency in Buildings, Asilomar, CA.

Hugenschmidt, H. and J. Janssen. 1999. "Kyoto Protocol: New Market Opportunities or New Risks?" Swiss Derivatives Review (July).

IBHS \& SBA. 1999. "Open for Business: A Disaster Planning Toolkit for the Small Business Owner." Institute for Business and Home Safety, Boston, MA, and the U.S. Small Business Administration. (http://www.ibhs.org/docs/openforbusiness.pdf)

IBHS. 2001. "The Ten Most Wanted: A Search for Solutions to Reduce Recurring Losses from Natural Disasters." Institute for Business and Home Safety, Boston, MA. (http://www.ibhs.org/research_library/downloads/292.pdf)

Insurance Information Institute. 1997; 1999; 2000. The Insurance Fact Book. Insurance Information Institute, New York, NY.

IPCC. 1998. IPCC Workshop on Rapid Non-Linear Climate Change, Noordwijkerhout, the Netherlands, 31 March - 2 April. Intergovernmental Panel on Climate Change.

ISO. 1994. The Impact of Catastrophes on Property Insurance. Insurance Services Office, New York, NY (January) (http://www.iso.com/docs/stud006.htm).

Jarvis, D., Chinn, S., Luczynska, C., and Burney, P. 1996. "Association of repiratory symptoms and lung function in young adults with the use of gas appliances." The Lancet 347 426-431.

Jones, Richard. 2000. Interview. Hartford Steam Boiler Insurance \& Inspection Company (February 25).

Klaus, A, U. Straub, and C. Teuber. 1992. "Pipes and water damage." Sigma No. 2/1999. Swiss Reinsurance Company, Zurich, Switzerland.. Kluver, M. 1994.

"Observations from the Southern California Wildland Fires." Building Standards (January-February), p. 12-17.

Kohler, D. 1999. "SIP: The Sustainability Investment Partners in Practise." Proceedings of More $14^{\text {th }}$-- Seminar on "Global Climate Change", London 16-17 September. Association Internationale pour l'Etude de l'Economie de l'Assurance, Geneva.

Kovacs, P. 2000. Insurance Bureau of Canada, personal communication.

Levick, D. "Insurers in State Awash in Claims Related to Water Damage". The Hartford Courant, Jan. 20, 1996. 
Lowe, R.J. 2001a. A Review Of Recent And Current Initiatives On Climate Change And Its Impact On The Built Environment: Impact, Effectiveness And Recommendations. Crisp Consultancy Commission 01/04 - Final Report. Leeds Metropolitan University Centre for the Built Environment. http://www.crispuk.org.uk/reports/0104_fr.pdf

Lowe, R. J. 2001b. "Really Rethinking Construction.” Building Research \& Information, 29(5):409-412.

Matthews, P. B., M.P. Sheffield, J.E. Andre, J.H. Lafayette, J.M. Roethen, and E. Dobkin. 1999. "Insolvency: Will Historic Trends Return?" Best's Review-Property-Casualty Insurance Edition, p. 59 (March) (http://www.bestreview.com/pc/1999-03/trends.html).

Meier, A. 1996. "Preventing Urban Heat Catastrophes.” Home Energy, pp. 6-7 (July/August).

Mestel, R. 1995a. "White Paint on a Hot Tin Roof." New Scientist, 25 March: 34-37.

Mills, E. 1993. “A Graceful Exit.” Newsletter of the International Association for Energy-Efficient Lighting, pp. 10-11, Stockholm, Sweden.

Mills, E. 1996. "Energy Efficiency: No-Regrets Climate Change Insurance for the Insurance Industry." Research Review: Journal of the Society for Insurance Research, Marietta, GA (Winter).

Mills, E. 2001. "When the Lights Go Out". Bests Review. July. P. 73-77.

Mills, E. 2002a. "The Insurance and Risk Management Industries: New Players in The Delivery of Energy-Efficient and Renewable Energy Products and Services". Energy Policy (in press).

Mills, E. 2002b. "Insurers in the Greenhouse". Journal of Insurance Regulation (in press).

Mills, E. and A. Rosenfeld. 1996. "Consumer Non-Energy Benefits as a Motivation for Making Energy-Efficiency Improvements." Energy-The International Journal, $21(7 / 8): 707-720$.

Mills, E. and I. Knoepfel. 1997. "Energy-Efficiency Options for Insurance LossPrevention" Proceedings of the 1997 ECEEE Summer Study, European Council for an Energy-Efficient Economy, Copenhagen, Denmark. Lawrence Berkeley National Laboratory Report 40426. http://eande.lbl.gov/CBS/PUBS/noregrets.html.

Mills, E., E. Lecomte, and A. Peara. 2001. "Perspectives of the U.S. Insurance Industry on Climate Change". Lawrence Berkeley National Laboratory Report No. 45185. $165 \mathrm{pp}$.

Moomaw, W. R., J. R. Moreira, K. Blok, D. Greene, K. Gregory, T. Jaszay, T. Kashiwagi, M. Levine, M. MacFarland, N. S. Prasad, L. Price, H. Rogner, R. Sims, F. Zhou, E. Alsema, H. Audus, R. K. Bose, G. M. Jannuzzi, A. Kollmuss, L. Changsheng, E. Mills, K. Minato, S., Plotkin, A. Shafer, A. C. Walter, R. Ybema, J. de Beer, D. Victor, R. Pichs-Madruga, H. Ishitani. 2001. "Technological and Economic Potential of Greenhouse Gas Emissions Reduction." Chapter 3 In Climate Change 2001: Mitigation. Intergovernmental Panel on Climate Change, United Nations and World Meteorological Organization, Geneva. Working Group 3. 
Munich Re. 1973. Flood Inundation. Munich Reinsurance Company, Munich, Germany. Munich Re. 1999. Topics 2000: Natural Catastrophes -- The Current Position. Munich Re Group, Geoscience Research Group, Munich, Germany. Report 2895-M-e.

Munich Re. 2000. Review of Natural Disasters 1999, Munich Re, (plus supplementary data and analysis provided by Angelika Wirtz at Munich Re). Report 2946-M-e

PCS. 2000. Catastrophe Loss Database. Property Claim Services, a unit of ISO, Inc. 27 pp.

Peara, A. and E. Mills. 1999. "Climate for Change, An Actuarial Perspective on Global Warming and its Potential Impact on Insurers." Contingencies: Journal of the American Academy of Actuaries, pp. 16-25 (January/February).

Quirke, K. 1994. "Global Warming and Increasing Catastrophe Losses: The Changing Climate of Financing Risk." Journal of Insurance Regulation, Vol. 12, No. 4. (Summer), pp. 452-466.

Rosenfeld, A.H., H. Akbari, S. Bretz, B.L. Fishman, D.M. Kurn, D. Sailor, H. Taha. 1995. "Mitigation of Urban Heat Islands: Materials, Utility Programs, Updates." Energy and Buildings, 22:255-265.

Ross, A., 2000. "Reflections on the Future: Climate Change and its Impacts on the Insurance Industry," Paper No. 8, Ontario: University of Western Ontario and Institute for Catastrophic Loss Reduction.

Ruquet, M.S. 2002. "Contractors Insurance Crisis Spreads." National Underwriter, June 17, p. 14.

Sardinsky, R. and S. Hawthorne. 1994. "LED Exit Signs: Improved Technology Leads the Way to Energy Savings.” E Source Tech Update. E Source. Boulder, Colorado.

Scott, M., S. Gupta, E. Jáuregui, J. Nwafor, D. Satterthwaite, Y.A.D.S. Wanasinghe, T. Wilbanks, M. Yoshino, U. Kelkar, L. Mortsch, and J. Skea. 2001. "Human Settlements, Energy, and Industry." Chapter 8 in "Climate Change 2001: Impacts, Vulnerability, and Adaptation." Intergovernmental Panel on Climate Change, United Nations and World Meteorological Organization, Geneva. (see http://www.grida.no/climate/ipcc tar/wg2/305.htm)

Storebrand. 1999. "Environmental Status 1998." Storebrand Insurance Company, Oslo, Norway. (http://www.storebrand.no/storebrand/internett/english_om.nsf).

Swiss Re. 1997. Too Little Reinsurance of Natural Disasters in Many Markets, Sigma Report No. 7/1997, Swiss Re, Zurich. (http://www.swissre.com/e/publications/publications/sigma1/sigma_071.Paras.00 14.File.pdf).

Swiss Re. 1998. Climate Research Does Not Remove Uncertainty: Coping with the Risks of Climate Change, Swiss Reinsurance Company, Zurich. (http://www.swissre.com/e/publications/publications/flyers1/archive6/environmen t.html).

Swiss Re. 2000a. Natural Catastrophes and Man-Made Disasters in 1999, Swiss Re, Zurich. (http://www.swissre.com/e/publications/publications/naturall/twister.html). 
Swiss Re. 2000b. Swiss Re Environmental Report 1999, Swiss Reinsurance Company, Zurich, Switzerland. See

(http://www.swissre.com/e/issues/environmental/report1999.html).

Thorness, B. 1998. "Global Warning Signs Should Insurance Focus on Causes or Effects of Climate Change?" Claims Magazine, (May), (http://www.claimsmag.com/global.html).

UNEP. 1995. Statement of Environmental Commitment by the Insurance Industry. United Nations Environmental Program, Environment and Trade, Geneva.

Unnewehr, D. 1999. "Property-Casualty Insurance and the Climate Change Debate: A Risk Assessment." American Insurance Association, Washington, D.C.

USDOE. 1999. Model Guidelines for Incorporating Energy Efficiency and Renewable Energy into State Energy Plans. Prepared by the United States Department of Energy, Offices of Emergency Management and Energy Efficiency and Renewable Energy. September.

Vellinga, P. V., E. Mills, L. Bowers, G. Berz, S. Huq, L. Kozak, J. Paultikof, B. Schanzenbacker, S. Shida, G. Soler, C. Benson, P. Bidan, J. Bruce, P. Huyck, G. Lemcke, A. Peara, R. Radevsky, C. van Schoubroeck, A. Dlugolecki. 2001. "Insurance and Other Financial Services." Chapter 8 in "Climate Change 2001: Impacts, Vulnerability, and Adaptation." Intergovernmental Panel on Climate Change, United Nations and World Meteorological Organization, Geneva. (see http://www.grida.no/climate/ipcc tar/wg2/321.htm).

Vine, E., E. Mills, A. Chen. 1998. Energy-Efficiency and Renewable Energy Options For Risk Management and Insurance Loss Reduction. Lawrence Berkeley National Laboratory Report No. 41432. Energy, 25 (2000): 131-147.

Watson, R. et al. 2001. "Climate Change 2001: Synthesis Report" Intergovernmental Panel on Climate Change, United Nations and World Meteorological Organization, Geneva.

Zeng, L. and P.J. Kelly. 1997. A Preliminary Investigation of the Trend of Flood Events in the United States. Presented at the National Association of Real Estate Investment Managers Senior Officer Property Insurance Forum, Boston, (March 18-19). Arkwright Mutual Insurance Company.

Zwirner, O. 2000. "Impact of Greenhouse Gas Mitigation on the Insurance Industry." in Bernstein, L. and J. Pan, eds. Sectoral Economic Costs and Benefits of GHG Mitigation: Proceedings of an IPCC Expert Meeting, Eisenach, Germany, 14-15 February 2000, pp. 260-269. 
Table 1. Intergovernmental Panel on Climate Change (IPCC) findings on the impacts of climate change on the insurance industry: past (observed) changes and projected changes during the $21^{\text {st }}$ century. Adapted from Vellinga et al. (2001).

\begin{tabular}{|c|c|c|c|c|c|}
\hline \multirow[t]{2}{*}{ Type of event } & \multirow[t]{2}{*}{$\begin{array}{l}\text { Changes in extreme climate } \\
\text { phenomena }\end{array}$} & \multirow{2}{*}{$\begin{array}{l}\text { Past (Observed) } \\
\text { changes } \\
\text { Likelihood* }\end{array}$} & \multirow{2}{*}{\multicolumn{2}{|c|}{$\begin{array}{l}\text { Future } \\
\text { (Projected) changes }\end{array}$}} & \multirow[t]{2}{*}{$\begin{array}{l}\text { Insurance Impacts } \\
\text { (high confidence) } * *\end{array}$} \\
\hline & & & & & \\
\hline \multicolumn{6}{|c|}{ Temperature Extremes } \\
\hline Heat wave & \multirow[t]{2}{*}{$\begin{array}{l}\text { Higher maximum temperatures, } \\
\text { more hot days and heat } \\
\text { waves*** over nearly all land } \\
\text { areas }\end{array}$} & \multirow[t]{2}{*}{$\begin{array}{l}\text { Likely, (mixed trends } \\
\text { for heatwaves in } \\
\text { several regions) }\end{array}$} & \multirow{2}{*}{\multicolumn{2}{|c|}{ Very likely }} & $\begin{array}{l}\text { Health, life, property, } \\
\text { business interruption }\end{array}$ \\
\hline $\begin{array}{l}\text { Heat wave' } \\
\text { droughts }\end{array}$ & & & & & $\begin{array}{l}\text { Health, crop, business } \\
\text { interruption }\end{array}$ \\
\hline $\begin{array}{l}\text { Frost, frost } \\
\text { heave }\end{array}$ & $\begin{array}{l}\text { Higher [Increasing] minimum } \\
\text { temperatures, fewer cold days, } \\
\text { frost days and cold waves*** } \\
\text { over nearly all land areas }\end{array}$ & $\begin{array}{l}\text { Very Likely, (cold } \\
\text { waves not treated by } \\
\text { WG1) }\end{array}$ & \multicolumn{2}{|c|}{ Very likely } & $\begin{array}{l}\text { Health, crop, property, } \\
\text { business interruption, } \\
\text { vehicle }\end{array}$ \\
\hline \multicolumn{6}{|c|}{ Rainfall and Other Precipitation Extremes } \\
\hline \begin{tabular}{l|l} 
Flash flood & $\mathrm{N}$ \\
$\mathrm{c}$
\end{tabular} & \multirow[t]{2}{*}{$\begin{array}{l}\text { More intense precipitation } \\
\text { events }\end{array}$} & \multirow[t]{2}{*}{$\begin{array}{l}\text { Likely over many } \\
\text { Northern Hemisphere } \\
\text { mid- to high latitude } \\
\text { land areas }\end{array}$} & \multirow{2}{*}{\multicolumn{2}{|c|}{$\begin{array}{l}\text { Very likely, over } \\
\text { manyareas }\end{array}$}} & $\begin{array}{l}\text { Property, flood, } \\
\text { vehicle, business } \\
\text { interruption, life, } \\
\text { health }\end{array}$ \\
\hline $\begin{array}{l}\text { Flood, } \\
\text { inundation, } \\
\text { mudslide }\end{array}$ & & & & & $\begin{array}{l}\text { Property, flood, crop, } \\
\text { marine, business } \\
\text { interruption }\end{array}$ \\
\hline $\begin{array}{l}\text { Summer } \\
\text { drought, land } \\
\text { subsidence, } \\
\text { wildfire }\end{array}$ & $\begin{array}{l}\text { Increased summer drying and } \\
\text { associated risk of drought }\end{array}$ & Likely, in a few areas & \multicolumn{2}{|c|}{$\begin{array}{l}\text { Likely over most mid- } \\
\text { latitude continental } \\
\text { interiors (lack of } \\
\text { consistent projections } \\
\text { in other areas) }\end{array}$} & Crop, property, health \\
\hline $\begin{array}{l}\text { Snowstorm, ice } \\
\text { storm, } \\
\text { avalanche }\end{array}$ & \multirow[t]{2}{*}{$\begin{array}{l}\text { Increased intensity of mid- } \\
\text { latitude storms*** }\end{array}$} & $\begin{array}{l}\text { Medium likelihood of } \\
\text { increase in Northern } \\
\text { Hemisphere, decrease } \\
\text { in Southern } \\
\text { Hemisphere }\end{array}$ & \multirow{2}{*}{\multicolumn{2}{|c|}{$\begin{array}{l}\text { Little agreement among } \\
\text { current models }\end{array}$}} & $\begin{array}{l}\text { Property, crop, } \\
\text { vehicle, aviation, life, } \\
\text { business interruption }\end{array}$ \\
\hline Hailstorm & & & & & $\begin{array}{l}\text { Crop, vehicle, } \\
\text { property, aviation }\end{array}$ \\
\hline $\begin{array}{l}\text { Drought and } \\
\text { floods }\end{array}$ & $\begin{array}{l}\text { Intensified droughts and floods } \\
\text { associated with El Nino events } \\
\text { in many different regions [See } \\
\text { also under droughts and } \\
\text { extreme precipitation events] }\end{array}$ & $\begin{array}{l}\text { Inconclusive } \\
\text { information }\end{array}$ & \multicolumn{2}{|c|}{ Likely } & $\begin{array}{l}\text { Property, flood, } \\
\text { vehicle, crop, marine, } \\
\text { business interruption, } \\
\text { life, health }\end{array}$ \\
\hline $\begin{array}{l}\text { Mid-latitude } \\
\text { windstorm }\end{array}$ & \multirow[t]{2}{*}{$\begin{array}{l}\text { Increased intensity of mid- } \\
\text { latitude storms } * * *\end{array}$} & \multirow{2}{*}{\multicolumn{2}{|c|}{$\begin{array}{l}\text { No compelling evidence for } \\
\text { change }\end{array}$}} & \multirow[t]{2}{*}{$\begin{array}{l}\text { Little } \\
\text { agreement } \\
\text { between current } \\
\text { models }\end{array}$} & $\begin{array}{l}\text { Property, vehicle, } \\
\text { aviation, marine, } \\
\text { business interruption, } \\
\text { life }\end{array}$ \\
\hline Tornadoes & & & & & $\begin{array}{l}\text { Property, vehicle, } \\
\text { aviation, marine, } \\
\text { business interruption }\end{array}$ \\
\hline $\begin{array}{l}\text { Tropical storms, } \\
\text { including cyclones, } \\
\text { hurricanes and } \\
\text { typhoons }^{8}\end{array}$ & $\begin{array}{l}\text { Increase in tropical cyclone } \\
\text { peak wind intensities, mean } \\
\text { and peak precipitation } \\
\text { intensities**** }\end{array}$ & \multicolumn{2}{|l|}{$\begin{array}{l}\text { Wind extremes not } \\
\text { observed in the few } \\
\text { analyses available; } \\
\text { Insufficient data for } \\
\text { precipitation }\end{array}$} & $\begin{array}{l}\text { Likely, over } \\
\text { some areas }\end{array}$ & $\begin{array}{l}\text { Property, vehicle, } \\
\text { aviation, marine, } \\
\text { business interruption, } \\
\text { life }\end{array}$ \\
\hline
\end{tabular}




\begin{tabular}{|l|l|l|l|l|}
\hline Other Extremes & $\begin{array}{l}\text { Refer to entries above for higher } \\
\text { temperatures, increased tropical and } \\
\text { mid-latitude storms }\end{array}$ & $\begin{array}{l}\text { Refer to } \\
\text { relevant } \\
\text { entries above }\end{array}$ & $\begin{array}{l}\text { Refer to } \\
\text { relevant } \\
\text { entries above }\end{array}$ & $\begin{array}{l}\text { Life, property, vehicle, } \\
\text { aviation, marine, } \\
\text { business interruption }\end{array}$ \\
\hline $\begin{array}{l}\text { Tidal surge (in } \\
\text { association with onshore } \\
\text { gales), coastal inundation }\end{array}$ & $\begin{array}{l}\text { Refer to entries above for increased } \\
\text { tropical cyclones, Asian summer } \\
\text { monsoon, and and intensity of mid- } \\
\text { latitude storms }\end{array}$ & $\begin{array}{l}\text { Refer to } \\
\text { relevant } \\
\text { entries above }\end{array}$ & $\begin{array}{l}\text { Refer to } \\
\text { relevant } \\
\text { entries above }\end{array}$ & $\begin{array}{l}\text { Life, marine, property, } \\
\text { crop }\end{array}$ \\
\hline Flood and drought & $\begin{array}{l}\text { Increased Asian summer monsoon } \\
\text { precipitation variability }\end{array}$ & $\begin{array}{l}\text { Not treated } \\
\text { by IPCC }\end{array}$ & Likely & $\begin{array}{l}\text { Crop, property, health, } \\
\text { life }\end{array}$ \\
\hline
\end{tabular}

* Likelihood refers to estimates of confidence developed by IPCC: very likely ( $90-99 \%$ chance); likely (66-90\% chance).

**High confidence refers to probabilities between 2 -in-3 and $95 \%$.

*** Information from Working Group I, Technical Summary, Section F.5.

**** Changes in regional distribution of tropical cyclones are possible but have not been established. 
Table 2. Physical perils and insurance coverage addressed by energy-efficiency and renewable energy technologies \& strategies (Vine et al. 1998).

\begin{tabular}{|l|l|}
\hline & $\begin{array}{l}\text { Number of } \\
\text { neasures offering } \\
\text { penefit }\end{array}$ \\
\hline \hline Physical Perils & \\
\hline Extreme Temperature Episodes & $\mathbf{1 6}$ \\
\hline Fire \& Wind Damage & $\mathbf{3 8}$ \\
\hline Home or Workplace Indoor Air Quality Hazards & $\mathbf{3 8}$ \\
\hline Home or Workplace Safety Hazards & $\mathbf{2 1}$ \\
\hline Ice \& Water Damage & $\mathbf{1 7}$ \\
\hline Outdoor Pollution or Other Environmental Hazard & $\mathbf{1 7}$ \\
\hline Power Failures & $\mathbf{3 5}$ \\
\hline Theft and Burglary & $\mathbf{6}$ \\
\hline & \\
\hline Insurance Coverage - Commercial Lines & \\
\hline Boiler \& Machinery & $\mathbf{1 5}$ \\
\hline Builder's Risk & $\mathbf{4}$ \\
\hline Business Interruption & $\mathbf{2 1}$ \\
\hline Commercial Property Insurance & $\mathbf{3 6}$ \\
\hline Completed Operations Liability & $\mathbf{1 4}$ \\
\hline Comprehensive General Liability & $\mathbf{4 5}$ \\
\hline Contractors Liability & $\mathbf{1 4}$ \\
\hline Environmental Liability & $\mathbf{1 2}$ \\
\hline Health/Life Insurance & $\mathbf{3 9}$ \\
\hline Product Liability & $\mathbf{5}$ \\
\hline Professional Liability & $\mathbf{1 9}$ \\
\hline Service Interruption & $\mathbf{2 1}$ \\
\hline Workers' Compensation & $\mathbf{3 5}$ \\
\hline & \\
\hline Insurance Coverage - Personal Lines & \\
\hline Health/Life Insurance & $\mathbf{3 5}$ \\
\hline Homeowners Insurance & $\mathbf{2 6}$ \\
\hline & \\
\hline
\end{tabular}

${ }^{1}$ The numbers in this column refer to unique technologies and cover all technologies in Table 4 of Vine et al. (1998).

${ }^{2}$ The environmental benefits of improving the outdoor air quality, reducing vulnerabilities to power outages, and reducing greenhouse gases are cross-cutting and thus are not included in this table. 
Table 3. Insurance-related activities involving energy efficiency and renewable energy (Mills 2002a).

\begin{tabular}{|c|c|c|c|c|c|c|c|c|c|c|}
\hline & Country & $\begin{array}{l}\text { Information } \\
\text { \& Education } \\
\end{array}$ & $\begin{array}{c}\text { Financial } \\
\text { Incentives }\end{array}$ & $\begin{array}{c}\text { Energy } \\
\text { Savings } \\
\text { Insurance }\end{array}$ & \begin{tabular}{|c|} 
Direct \\
Investment \\
via Markets
\end{tabular} & \begin{tabular}{|c|} 
Technology \\
Demon- \\
strations \\
\end{tabular} & \begin{tabular}{|c|} 
Customer \\
Services \\
$\&$ Inspections \\
\end{tabular} & $\begin{array}{c}\text { Codes \& } \\
\text { Standards } \\
\end{array}$ & $\begin{array}{c}\text { Research \& } \\
\text { Development }\end{array}$ & $\begin{array}{l}\text { In-House } \\
\text { Energy } \\
\text { Management }\end{array}$ \\
\hline \multicolumn{11}{|l|}{ INSURANCE \& REINSURANCE COMPANIES } \\
\hline American International Group (AIG) & US & & & & & & & & & \\
\hline American Modern Insurance Group & Us & & & & & & & & & \\
\hline Aon Risk Services & Us & & & & & & & & & \\
\hline \multicolumn{11}{|l|}{\begin{tabular}{|l} 
Bankers Insurance Group \\
Blue Cross \& Blue Shield Mutual of Ohio
\end{tabular}} \\
\hline Blue Cross \& Blue Shield Mutual of Ohio & US & & & & & & & & & \\
\hline Boiler Inspection \& Insurance Company & CA & & & & & & & & & \\
\hline CGNU (formerly General Accident) & UK & & & & & & & & & \\
\hline Chubb & Us & & & & & & & & & \\
\hline Connecticut Mutual Life Insurance Home Office & us & & & & & & & & & \\
\hline Continental Insurance & US & & & & & & & & & \\
\hline Delta Lloyd Verzekeringsgroup NV & NL & & & & & & & & & \\
\hline Developers Professional Insurance Company (DPIC) & Us & & & & & & & & & \\
\hline \begin{tabular}{|l|l|l} 
Employers Re \\
\end{tabular} & US & & & & & & & & & \\
\hline \begin{tabular}{|l|} 
First Treasury \\
\end{tabular} & $C A$ & & & & & & & & & \\
\hline FM Global (formerly Arkwright Mutual) & us & & & & & & & & & \\
\hline Gerling & UK & & & & & & & & & \\
\hline Grange Mutual & US & & & & & & & & & \\
\hline Guy Carpenter and Company & us & & & & & & & & & \\
\hline Hanover & Us & & & & & & & & & \\
\hline Harleysville Mutual Insurance Company & US & & & & & & & & & \\
\hline Harttord Steam Boiler (HSB/PT \& Canadian Subsidiary) & us & & & & & & & & & \\
\hline Independent Insurance & UK & & & & & & & & & \\
\hline ITT Hartford Group, Incorporated & Us & & & & & & & & & \\
\hline $\begin{array}{l}\text { Johnson \& Higgins } \\
\end{array}$ & Us & & & & & & & & & \\
\hline Lloyds of London (NatureSave Insurance) & UK & & & & & & & & & \\
\hline Milwaukee Insurance & US & & & & & & & & & \\
\hline Minnesota Mutual Life Insurance Company & Us & & & & & & & & & \\
\hline Munich Re & $\mathrm{D}$ & & & & & & & & & \\
\hline Nationwide Mutual Insurance Company. Inc. & us & & & & & & & & & \\
\hline New York Life Insurance \& Annuity Corp. & US & & & & & & & & & \\
\hline North American Capacity Insurance Co. (owned by Swiss Re) & Us & & & & & & & & & \\
\hline Pennsylvania Blue Shield & us & & & & & & & & & \\
\hline Phoenix Home Life Mutual Insurance Co. & Us & & & & & & & & & \\
\hline Progressive Auto Insurance & Us & & & & & & & & & \\
\hline Provident Life \& Accident Insurance Co. & us & & & & & & & & & \\
\hline Prudential Assurance & UK & & & & & & & & & \\
\hline Prudential Insurance Company of America, Inc. & us & & & & & & & & & \\
\hline Reinland Versicherungen & $\mathrm{D}$ & & & & & & & & & \\
\hline Royal Maccabees Life Insurance Company & us & & & & & & & & & \\
\hline 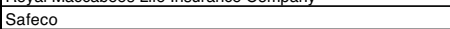 & us & & & & & & & & & \\
\hline St. Paul Fire and Marine Insurance & us & & & & & & & & & \\
\hline Sorema Re & $C A$ & & & & & & & & & \\
\hline State Compensation Insurance Fund & us & & & & & & & & & \\
\hline State Farm & us & & & & & & & & & \\
\hline State Farm Mutual Automobile Ins Co & us & & & & & & & & & \\
\hline Storebrand & $\mathrm{N}$ & & & & & & & & & \\
\hline Swiss Re & $\mathrm{CH}$ & & & & & & & & & \\
\hline USAA & us & & & & & & & & & \\
\hline USF\&G was (merged w/by St.Paul's Co.) & us & & & & & & & & & \\
\hline Victoria/Ergo & 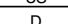 & & & & & & & & & \\
\hline Westbend Mutual & US & & & & & & & & & \\
\hline Zurich American Insurance Group / Steadfast & us & & & & & & & & & \\
\hline 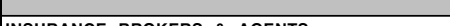 & & & & & & & & & & \\
\hline $\begin{array}{l}\text { INSURANCE BROKERS \& AGENTS } \\
\text { AON }\end{array}$ & & & & & & & & & & \\
\hline AON & US & & & & & & & & & \\
\hline $\begin{array}{l}\text { Clair Udell Group } \\
\text { Morris \& Mackenzie } \\
\end{array}$ & $\frac{U S}{C A}$ & & & & & & & & & \\
\hline NRG Savings Assurance & us & & & & & & & & & \\
\hline Willis CorroonnWillis Canada & US/CA & & & & & & & & & \\
\hline & & & & & & & & & & \\
\hline INSURANCE ORGANIZATIONS & & & & & & & & & & \\
\hline Advocates for Highwway and Auto Safety & us & & & & & & & & & \\
\hline American Insurance Association (AIA) & US & & & & & & & & & \\
\hline Institute for Business and Home Safety (IBHS) & US & & & & & & & & & \\
\hline Institute for Catastrophic Loss Reduction & CA & & & & & & & & & \\
\hline Insurance Institute for Highway Safety (IIHS) & Us & & & & & & & & & \\
\hline National Association of Independent Insurers & US & & & & & & & & & \\
\hline United Nations Environment Programme Insurance Initiative & $\mid$ Int'I & & & & & & & & & \\
\hline & & & & & & & & & & \\
\hline OTHERS & & & & & & & & & & \\
\hline Boston Edison Company & US & & & & & & & & & \\
\hline Building Air Quality Alliance (BAQA) & us & & & & & & & & & \\
\hline Building Code Assistance Project (BCAP) & US & & & & & & & & & \\
\hline Environmental Defense & US & & & & & & & & & \\
\hline y Administration (FHA) & US & & & & & & & & & \\
\hline International Energy Agency & Multi- & & & & & & & & & \\
\hline lowa Department of Natural Resources & US & & & & & & & & & \\
\hline Pacific Gas \& Electric Company & Us & & & & & & & & & \\
\hline Roofing Industry Committee on Wind Issues (RICOWI), & US & & & & & & & & & \\
\hline U.S. Department of Energy, Denver Support Office & US & & & & & & & & & \\
\hline U.S. Department of Transportation & US & & & & & & & & & \\
\hline U.S. Environmental Protection Agency & us & & & & & & & & & \\
\hline Waterhealth International & & & & & & & & & & \\
\hline
\end{tabular}


Table 4. Barriers to increased insurer involvement in energy efficiency and renewable energy.

\section{Technical Issues}

- Lack of quantitative documentation of benefits

- Insurer involvement in technology and $\mathrm{R} \& \mathrm{D}$ is limited in many cases

- Adverse side effects of improperly applied energy-efficient technologies

Nature of the Insurance Industry \& Marketplace

- Fragmentation - many types of insurers, each with different needs

- Difficult history with environmental issues, exemplified by Superfund litigation

- Regulatory hurdles to innovation, rate changes, etc.

Energy/Environment Community Perceptions of Insurers

- Perception of insurers as "cash cow"

- Poor understanding of how insurance business works

- Assumption that insurers will promote efficiency to battle climate change

Insurer Perceptions of Energy/Environment Community

- Adversarial history between environmentalists and industry

- Perception that efficiency is being used as "Trojan horse" by climate change advocates

Source: Mills 2002a. 


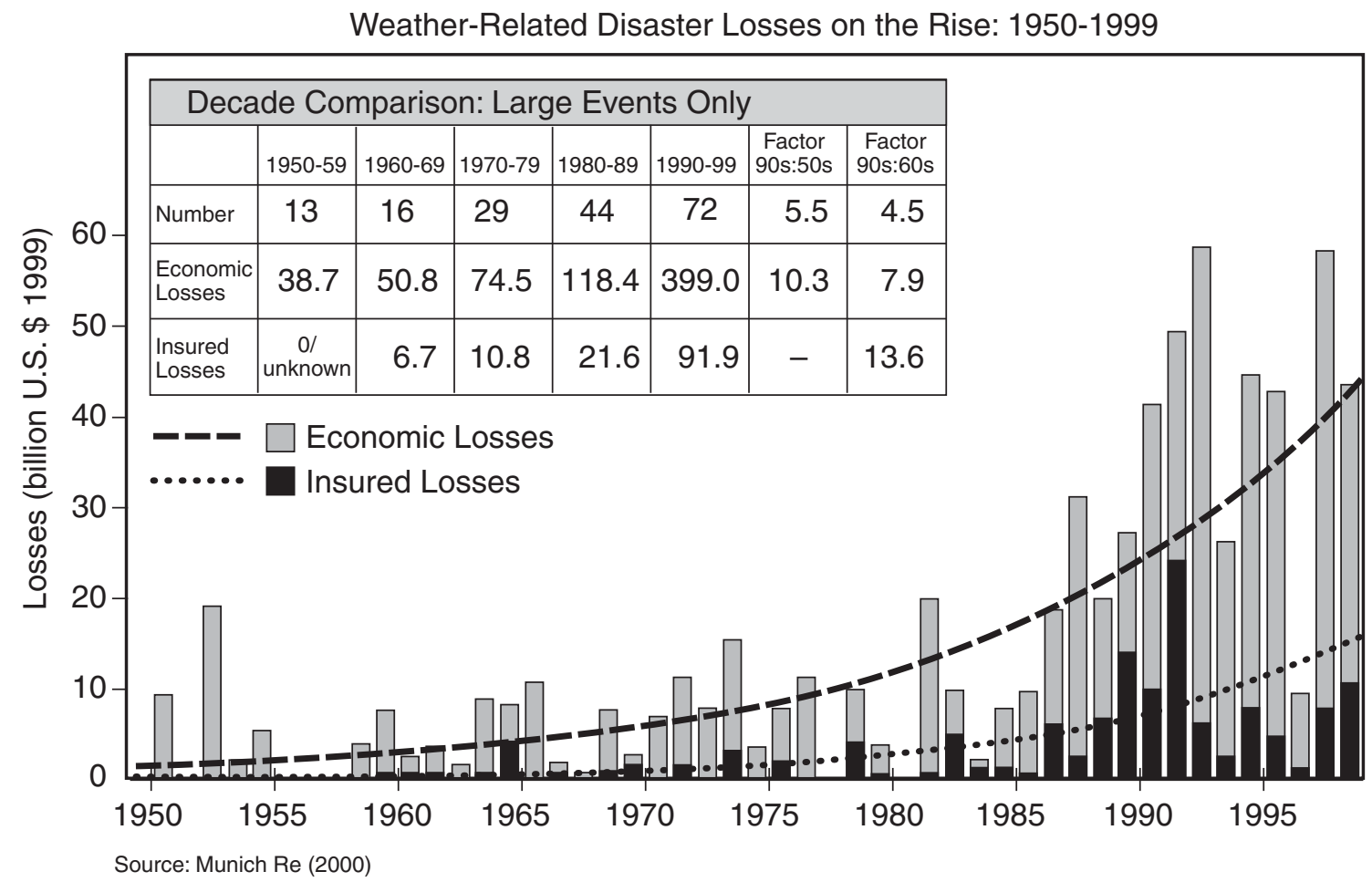

Figure 1. Inflation-corrected losses from natural disasters have increased dramatically since 1950. By including events of all sizes these totals would increase by approximately a factor of two. The cost data are adjusted for inflation. Population growth during 19501999 was 2.4-fold. Source: (Munich Re 2000). 


\section{Regional insurance coverage for weather- and non-weather-related natural disasters, 1985-1999}

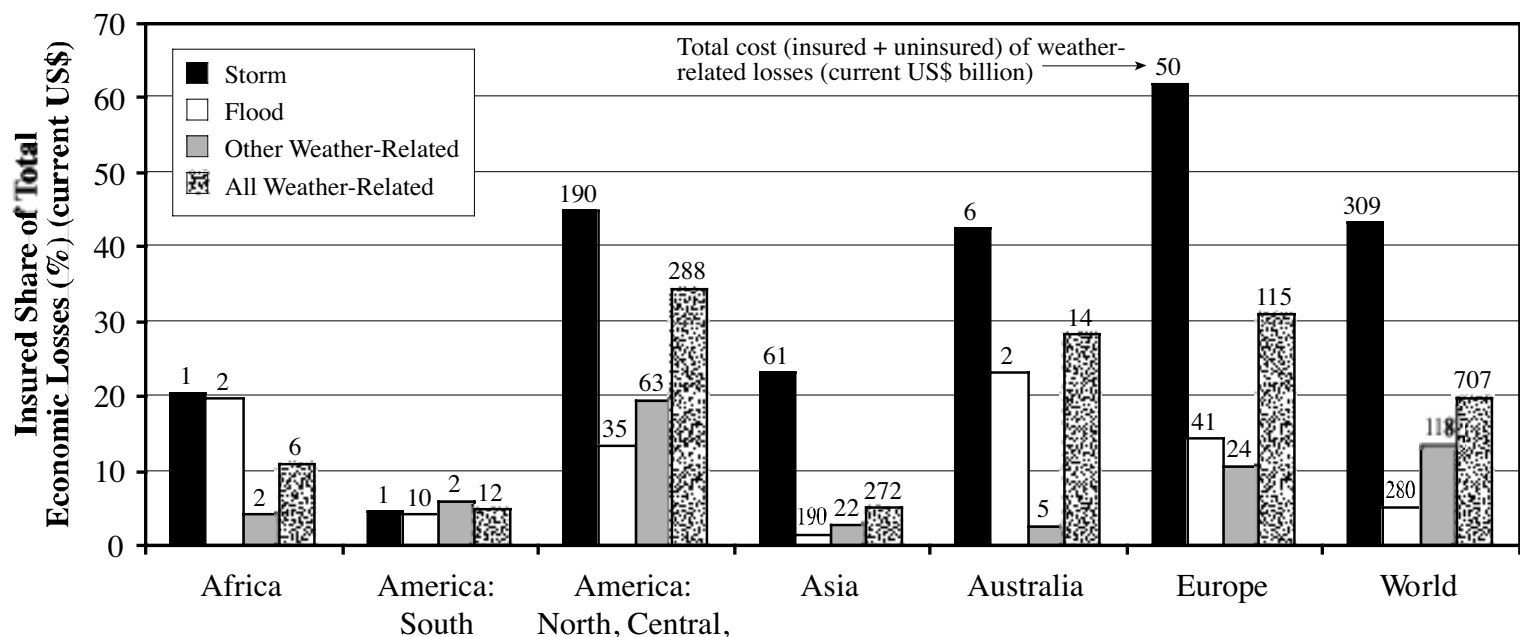

\begin{tabular}{|c|c|c|c|c|c|c|c|}
\hline \multicolumn{8}{|c|}{ Caribbean } \\
\hline $\begin{array}{l}\text { Number } \\
\text { of Events } \\
\text { Weather-Related }\end{array}$ & $\begin{array}{l}810 \\
91 \%\end{array}$ & $\begin{array}{l}610 \\
79 \%\end{array}$ & $\begin{array}{l}2,260 \\
87 \%\end{array}$ & $\begin{array}{l}2,730 \\
78 \%\end{array}$ & $\begin{array}{l}600 \\
87 \%\end{array}$ & $\begin{array}{l}1,810 \\
90 \%\end{array}$ & $\begin{array}{l}8,820 \\
85 \%\end{array}$ \\
\hline $\begin{array}{l}\text { Eatalities } \\
\text { Weather-Related }\end{array}$ & $\begin{array}{c}22,990 \\
88 \%\end{array}$ & $\begin{array}{c}56,080 \\
50 \%\end{array}$ & $\begin{array}{c}37,910 \\
72 \%\end{array}$ & $\begin{array}{c}429,920 \\
70 \%\end{array}$ & $\begin{array}{l}4,400 \\
95 \%\end{array}$ & $\begin{array}{l}8,210 \\
96 \%\end{array}$ & $\begin{array}{c}559,510 \\
70 \%\end{array}$ \\
\hline $\begin{array}{l}\text { Economic Losses } \\
\text { (current US\$ billion) } \\
\text { Weather-Related }\end{array}$ & $\begin{array}{c}7 \\
81 \%\end{array}$ & $\begin{array}{c}16 \\
73 \%\end{array}$ & $\begin{array}{l}433 \\
84 \%\end{array}$ & $\begin{array}{l}433 \\
63 \%\end{array}$ & $\begin{array}{c}16 \\
84 \%\end{array}$ & $\begin{array}{l}130 \\
89 \%\end{array}$ & $\begin{array}{l}947 \\
75 \%\end{array}$ \\
\hline $\begin{array}{l}\text { Insured Losses } \\
\text { (current US\$ billion) } \\
\text { Weather-Related }\end{array}$ & $\begin{array}{c}0.8 \\
100 \%\end{array}$ & $\begin{array}{l}0.8 \\
69 \%\end{array}$ & $\begin{array}{l}119 \\
86 \%\end{array}$ & $\begin{array}{c}22 \\
78 \%\end{array}$ & $\begin{array}{c}5 \\
74 \%\end{array}$ & $\begin{array}{l}40 \\
98 \%\end{array}$ & $\begin{array}{l}187 \\
87 \%\end{array}$ \\
\hline
\end{tabular}

Figure 2. The role of insurance in paying weather-related losses varies by event type and region, generally dominated by windstorm. "Other" includes weather-related events such as wildfire, landslides, land subsidence, avalanches, extreme temperature events, droughts, lightning, frost, and ice/snow damages. Total costs are higher than those in Figure 1 because these include smaller events. Rounding errors apply in some data labels. 


\section{Level of Risk under Varying Degrees of Climate Change}
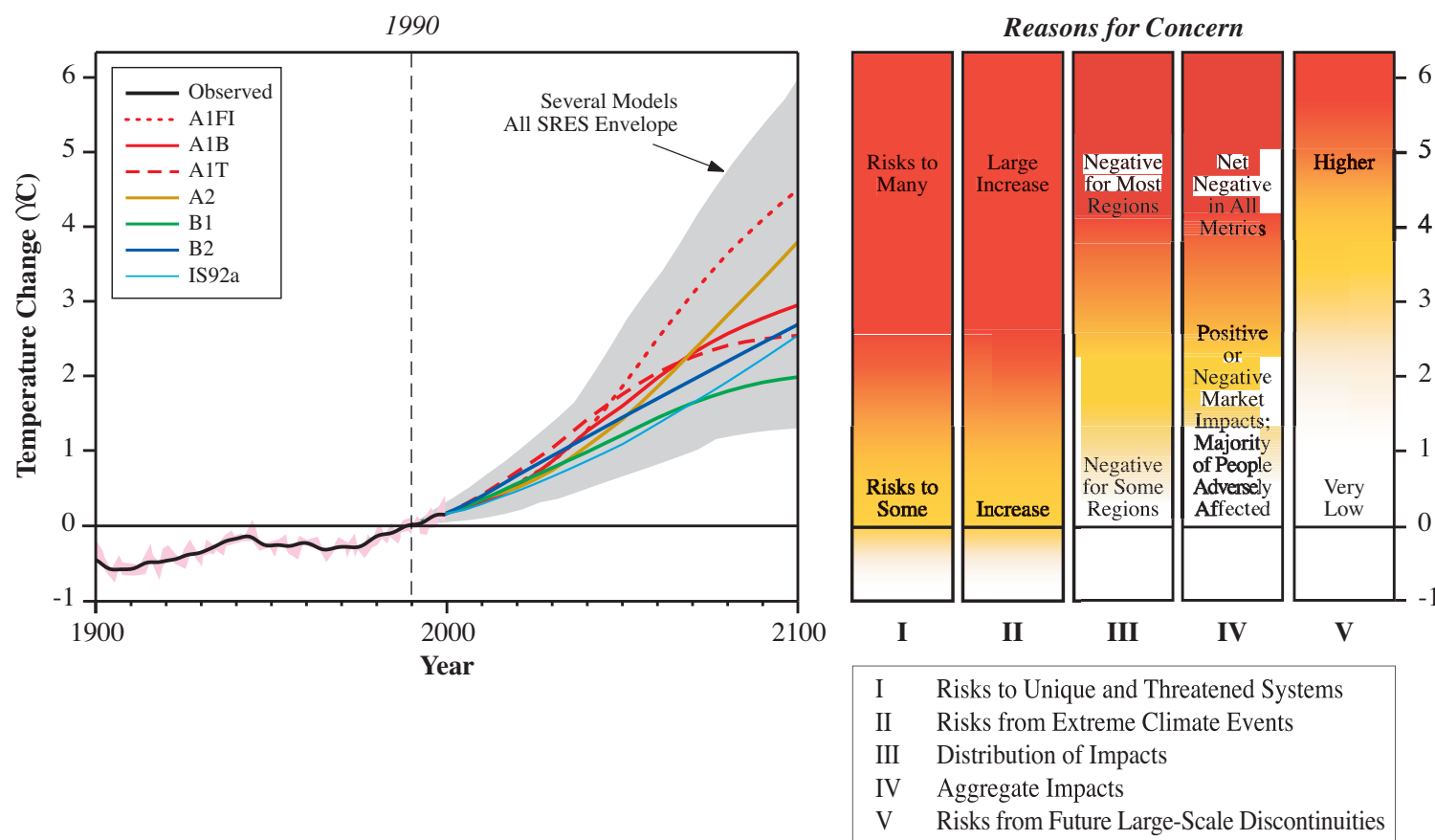

Figure 3. The left-hand chart shows the envelope of temperature-rise predictions from the latest IPCC Assessment (Watson et al. 2001). The right-hand chart shows the relative risks/benefits in various sectors associated with the range of projected temperature increases. 


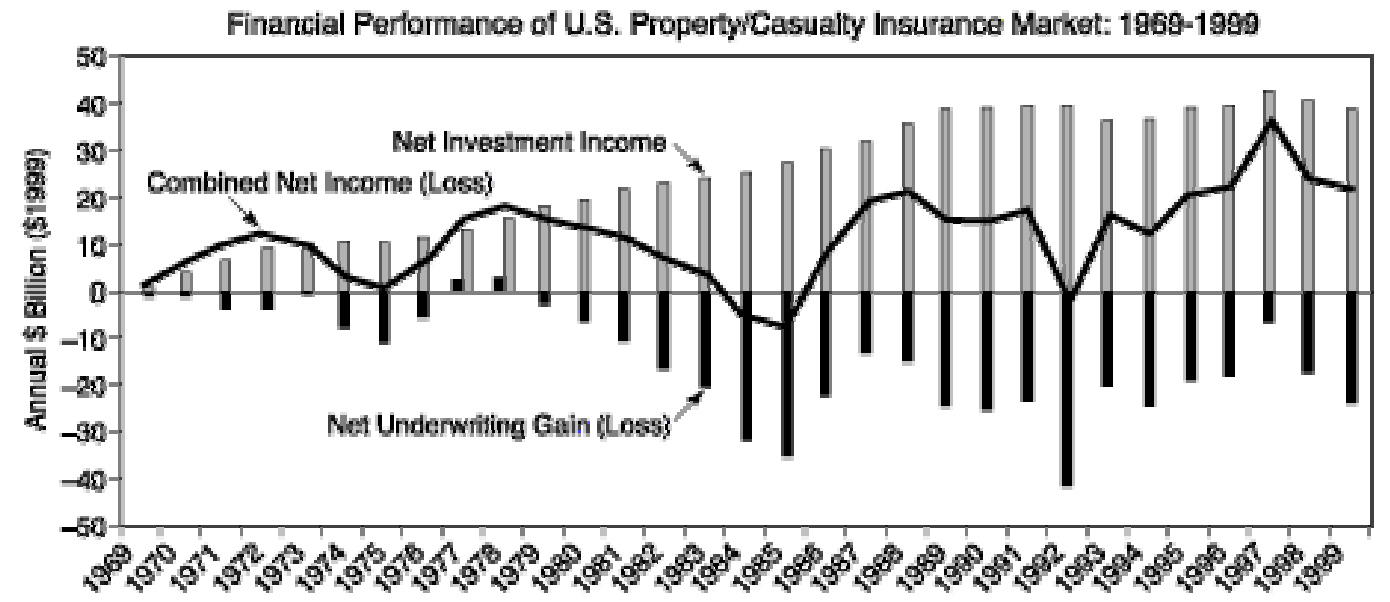

U.S. Catastrophe Losses and Insuror Insolvencles: 1969-1999

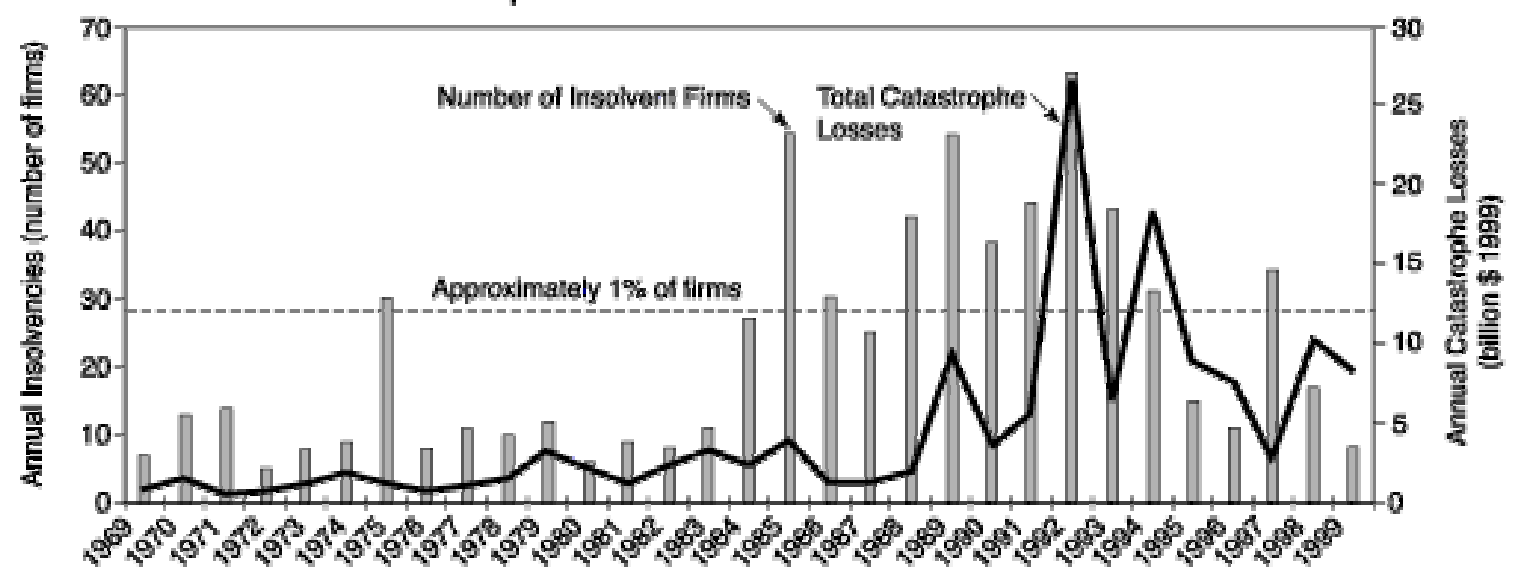

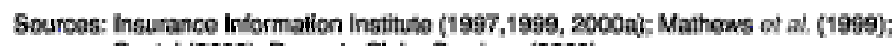
Gaslel (2000) Froery Clain Services poo0)

Figure 4a-b. Profitability and solvency of U.S. property/casualty insurers during periods of natural disasters. (a) Sensitivity of U.S. property/casualty insurance sector net financial results to investment income and underwriting gain/loss. Curve is the net result (b) Annual number of U.S. insolvencies (from all causes) and natural disaster losses: 1969-1999. Costs corrected for inflation using GDP deflators. Includes only insured losses of >\$5m through 1996 and $>25$ million beginning in 1997. Note that due to various lag times insolvencies do not necessarily take place in the same year as the precipitating event. Sources: ((Insurance Information Institute 1997, 1999, and 2000; Matthews et al. 1999; Gastel 2000; PCS 2000). 
Figure 5. Summer rainfall and subsidence claims in the UK 1975 - 1997. The rainfall data is for England and Wales, April to September, from the Climatic Research Unit, University of East Anglia, UK. The subsidence claim costs are not inflation-corrected, from the Association of British Insurers (Vellinga et al. 2001).

\section{Correlation between Soil Subsidence Costs and Periods of Drought}

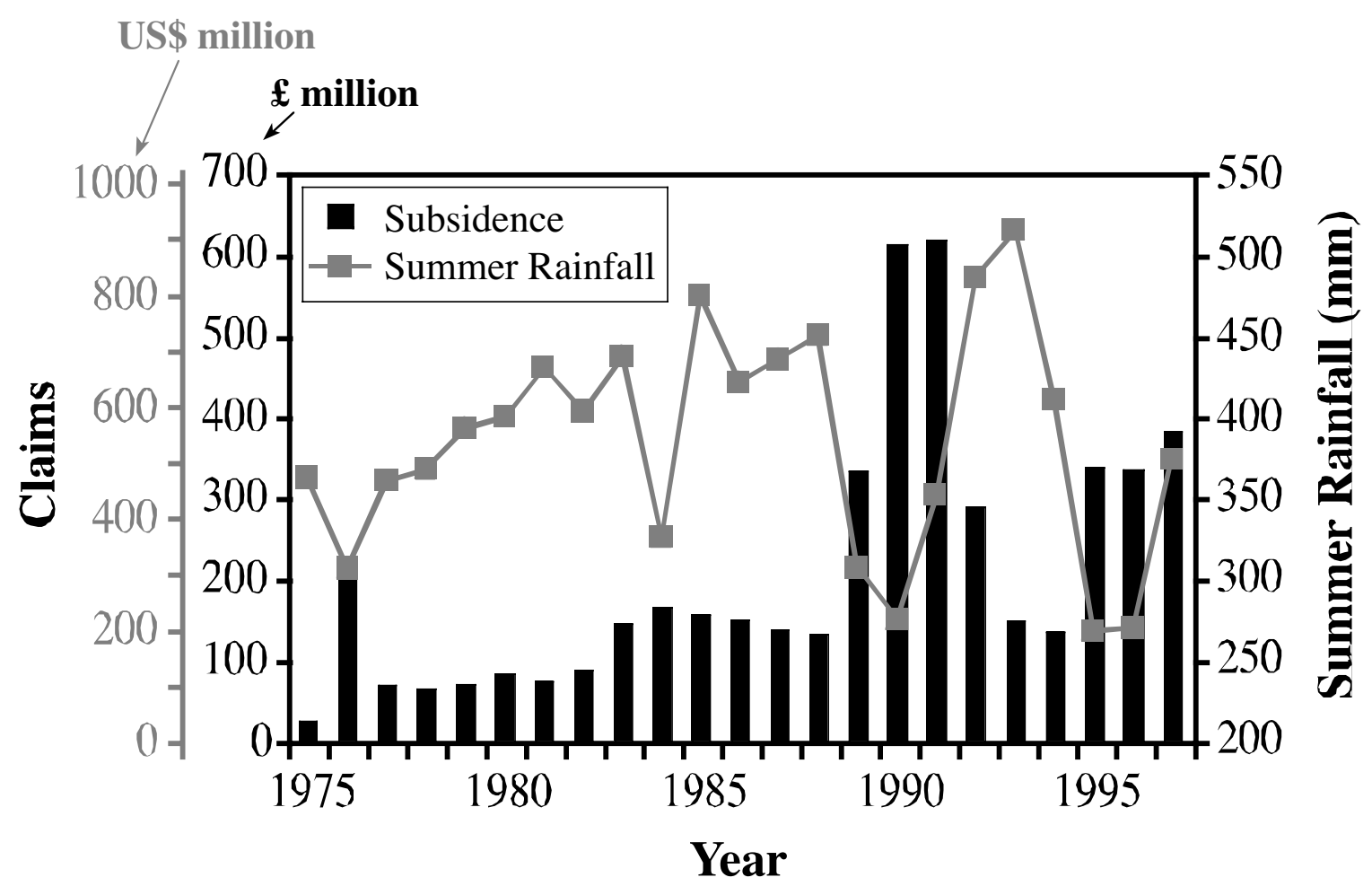




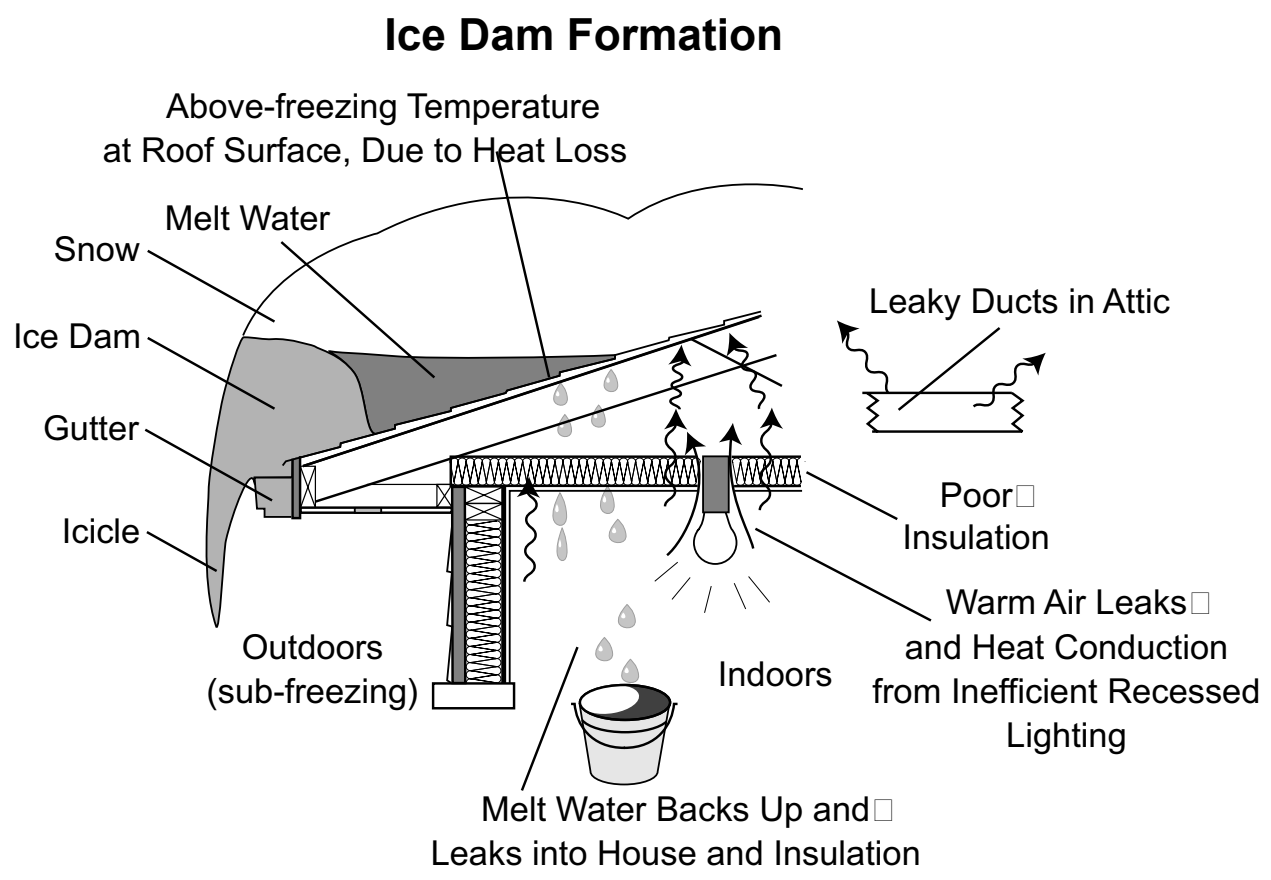

\section{Ice Dam Prevention with Energy Efficiency}

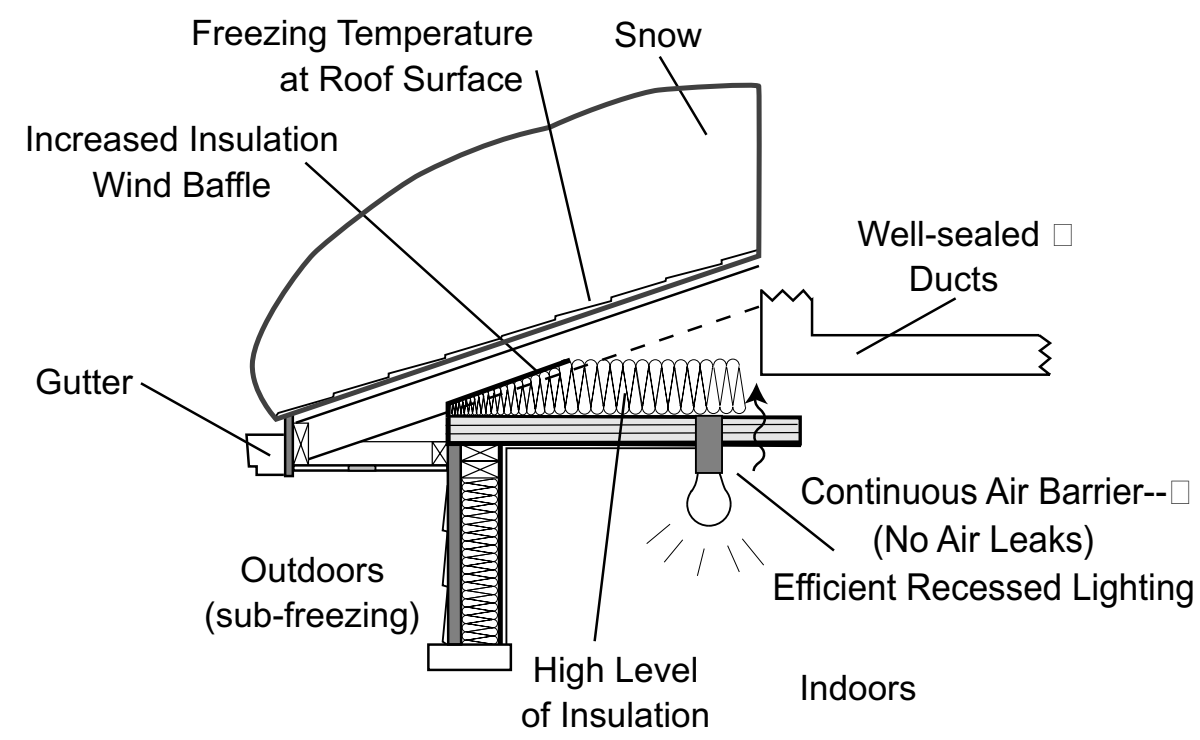

Figure 6. Energy-efficient features can contribute to reduced heat losses through roofs, and reduced risk of ice-dam formation. 


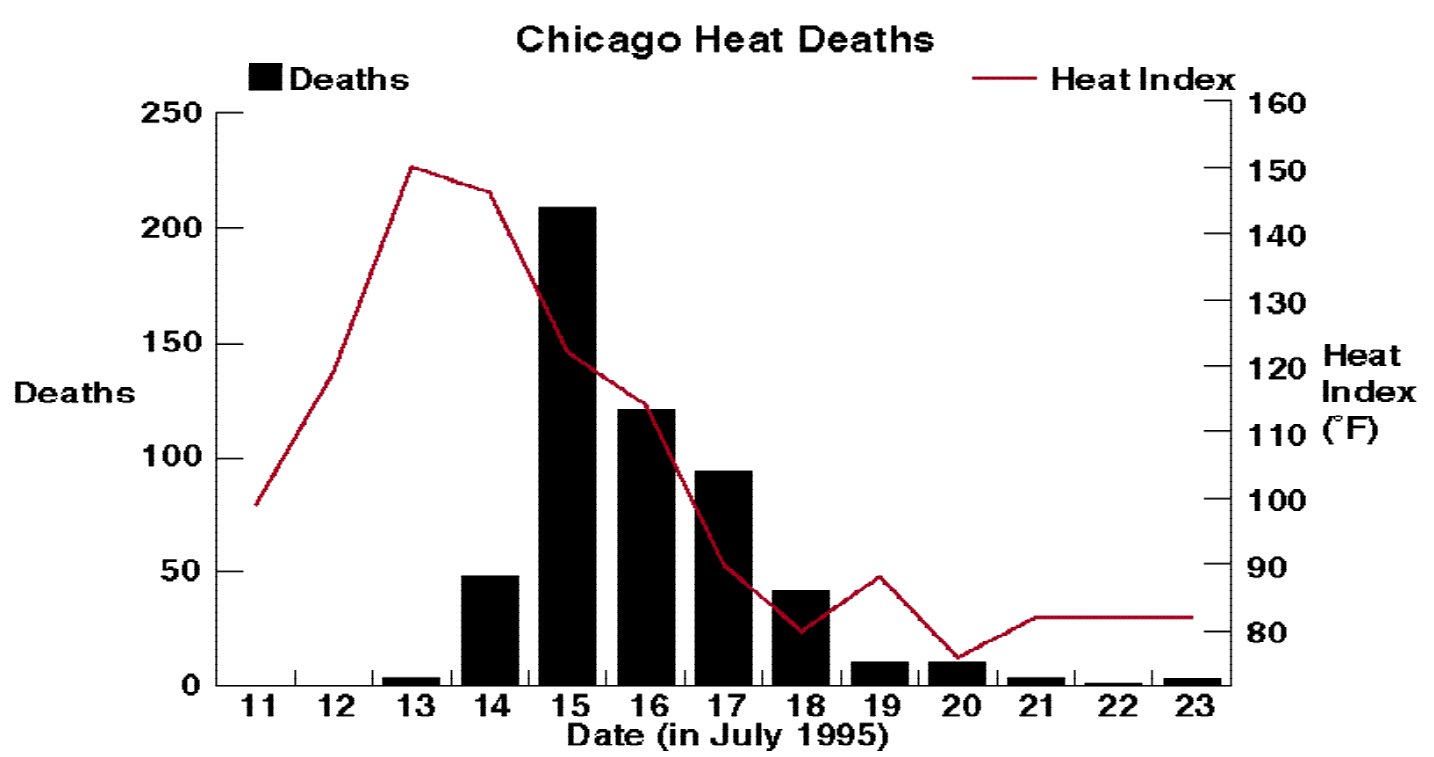

Figure 7a. The bars indicate numbers of above-normal deaths each day of the July 1995 heat wave in Chicago, and the curve shows the heat index, which reflects the combined effect of temperature and humidity.

\section{Performance of Weatherized and Unweatherized Apartments During Chicago Summer Heatwave in 1995}

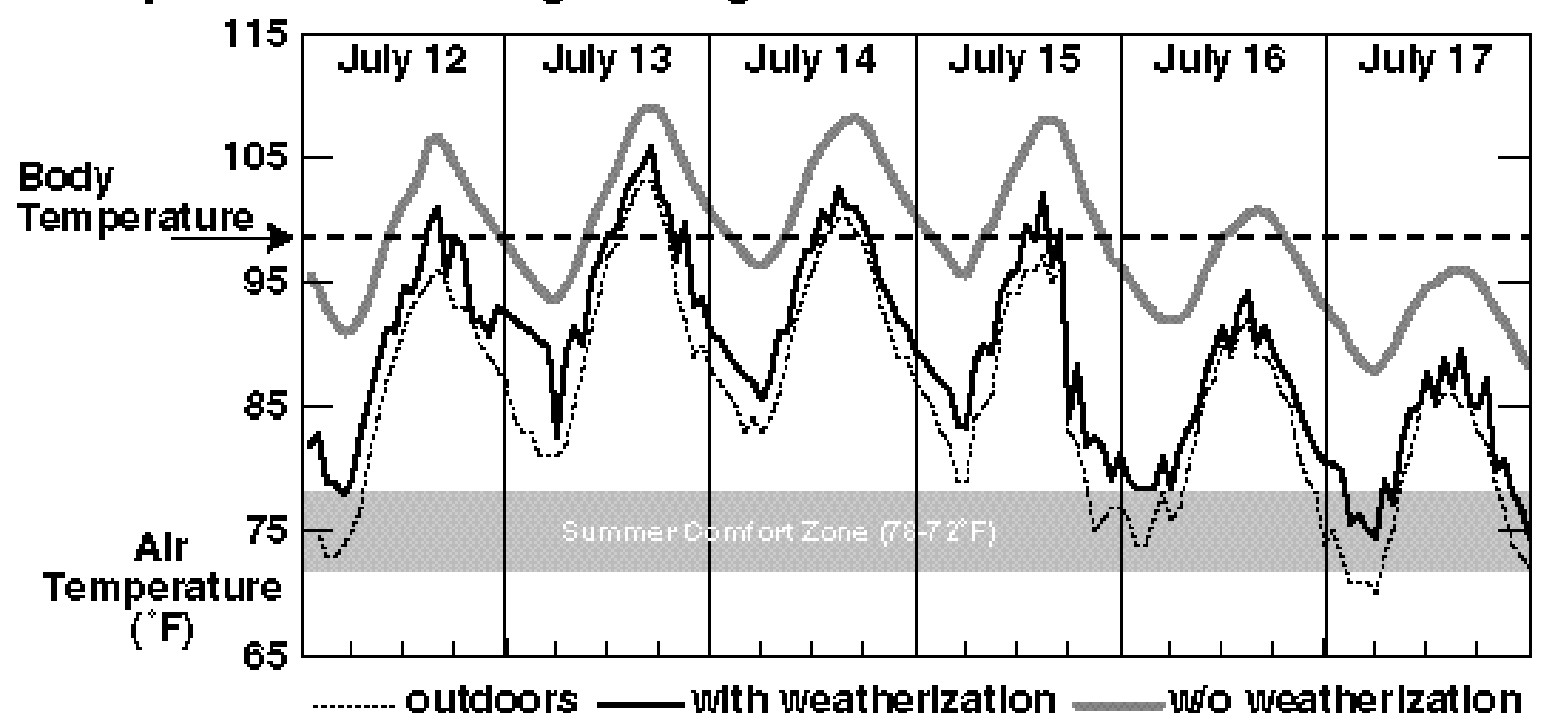

Figure $7 \boldsymbol{b}$. Computer-simulated indoor temperatures in the top floor of a prototypical 1940s two-story apartment building in Chicago during the July 1995 heatwave. In the existing building, top-floor temperatures reached $108^{\circ} \mathrm{F}(42 \mathrm{C})$ and remained high even after the outdoor temperatures had started to drop. The addition of attic insulation, white paint on the roof, and a ventilation system brought top floor temperatures in line with outdoor temperatures (Huang 1996; Meier 1996). 